\title{
Regulation of Net Bicarbonate Transport in Rabbit Cortical Collecting Tubule by Peritubular pH, Carbon Dioxide Tension, and Bicarbonate Concentration
}

\author{
Matthew D. Breyer, Juha P. Kokko, and Harry R. Jacobson \\ Department of Internal Medicine, University of Texas Health Science Center, Southwestern Medical School, Dallas, Texas 75235
}

\begin{abstract}
The effects of changes in peritubular $\mathrm{pH}$, carbon dioxide tension $\left(\mathrm{PCO}_{2}\right)$, and $\mathrm{HCO}_{3}^{-}$concentration on net $\mathrm{HCO}_{3}^{-}$transport was examined in in vitro perfused cortical collecting tubules (CCTs) from unpretreated New Zealand white rabbits. Lowering peritubular $\mathrm{HCO}_{3}^{-}$concentration and $\mathrm{pH}$ by reciprocal replacement of $\mathrm{HCO}_{3}^{-}$with $\mathrm{Cl}^{-}$, significantly stimulated net $\mathrm{HCO}_{3}^{-}$absorption. Lowering peritubular $\mathrm{HCO}_{3}^{-}$concentration and $\mathrm{pH}$, by substitution of $\mathrm{HCO}_{3}^{-}$with gluconate, while keeping $\mathrm{Cl}^{-}$concentration constant, also stimulated net $\mathrm{HCO}_{3}^{-}$absorption. Raising peritubular $\mathrm{HCO}_{3}^{-}$concentration and $\mathrm{pH}$, by reciprocal replacement of $\mathrm{Cl}^{-}$with $\mathrm{HCO}_{3}^{-}$, inhibited net $\mathrm{HCO}_{3}^{-}$absorption (or stimulated net $\mathrm{HCO}_{3}^{-}$secretion). When the tubule was cooled, raising peritubular $\mathrm{HCO}_{3}^{-}$concentration had no effect on net $\mathrm{HCO}_{3}^{-}$transport, suggesting these results are not due to the passive flux of $\mathrm{HCO}_{3}^{-}$down its concentration gradient.

The effect of changes in ambient $\mathrm{PCO}_{2}$ on net $\mathrm{HCO}_{3}^{-}$transport were also studied. Increasing the ambient $\mathrm{PCO}_{2}$ from $40 \mathrm{mmHg}$ to either 80 or $120 \mathrm{mmHg}$, allowing $\mathrm{pH}$ to fall, had no effect on net $\mathrm{HCO}_{3}^{-}$transport. Similarly, lowering ambient $\mathrm{PCO}_{2}$ to 14 mmHg had no effect on net $\mathrm{HCO}_{3}^{-}$transport. Simultaneously increasing peritubular $\mathrm{HCO}_{3}^{-}$concentration and $\mathrm{PCO}_{2}$, without accompanying changes in peritubular $\mathrm{pH}$, i.e., isohydric changes, stimulated net $\mathrm{HCO}_{3}^{-}$secretion to the same degree as nonisohydric increases in peritubular $\mathrm{HCO}_{3}^{-}$concentration. Likewise, isohydric lowering of peritubular $\mathrm{HCO}_{3}^{-}$concentration and $\mathrm{PCO}_{2}$ stimulated net $\mathrm{HCO}_{3}^{-}$absorption.

We conclude that: (a) acute changes in peritubular $\mathrm{HCO}_{3}^{-}$ concentration regulate acidification in the $\mathrm{CCT}$ and these effects are mediated by a transcellular process; (b) acute changes in ambient $\mathrm{PCO}_{2}$ within the physiologic range have no effect on $\mathrm{HCO}_{3}^{-}$transport in the in vitro perfused CCT; and (c) acute in vitro regulation of $\mathrm{CCT}$ acidification is independent of peritubular pH.
\end{abstract}

\section{Introduction}

Whole-animal studies have suggested a role for the distal nephron in the renal response to systemic acid-base disturbances (1-3).

Portions of this work were presented before the American Society of Nephrology, Washington, DC in 1984 and before the National Meeting of the American Federation of Clinical Research, Washington, DC in 1985. These portions have been published as abstracts (1985. Kidney Int. 27:278; 1985. Clin. Res. 33:479A).

Address reprint requests to Dr. Breyer, Department of Internal Medicine, Vanderbilt University Medical Center, Nashville, TN 37232.

Received for publication 16 September 1985 and in revised form 13 December 1985.

J. Clin. Invest.

(c) The American Society for Clinical Investigation, Inc.

$10021-9738 / 86 / 05 / 1650 / 11 \$ 1.00$

Volume 77, May 1986, 1650-1660
Isolated perfused tubule studies have demonstrated that the cortical collecting tubule (CCT) ${ }^{1}$ can display either net $\mathrm{HCO}_{3}^{-}$absorption or secretion (4-9). Thus, the CCT may participate in the final acidification or alkalinization of the urine. The parameters modulating net $\mathrm{HCO}_{3}^{-}$transport in the $\mathrm{CCT}$ have been only partially characterized. Isolated perfused tubule studies demonstrate that the direction of net $\mathrm{HCO}_{3}^{-}$transport by the CCT is influenced by the preexisting acid-base status of the animal from which the tubule was harvested $(4,5,7)$. Tubules harvested from animals with chronic metabolic acidosis demonstrate augmented $\mathrm{HCO}_{3}^{-}$absorption $(4,5,7,8)$, whereas tubules harvested from animals with chronic metabolic alkalosis display enhanced $\mathrm{HCO}_{3}^{-}$secretion $(4,5,9,10)$. Thus, transport of $\mathrm{HCO}_{3}^{-}$by the CCT can be influenced by chronic in vivo metabolic acid-base disturbances and furthermore appears to display a memory of the in vivo environment after being transferred to an in vitro system. The signal for this change in both the magnitude and direction of net $\mathrm{HCO}_{3}^{-}$transport by the CCT is unknown.

Respiratory acid-base disorders may also influence CCT acidification. Recent morphologic studies focusing on the CCT intercalated cell have suggested a role for $\mathrm{CO}_{2}$ in the regulation of CCT $\mathrm{HCO}_{3}^{-}$absorption. Of the two cell types identifiable by light microscopy, it is the intercalated, or mitochondrial-rich cell, rather than the principal cell that is thought to reabsorb $\mathrm{HCO}_{3}^{-}$via active $\mathrm{H}^{+}$secretion $(6,11-17)$. Electron microscopy of this cell shows significant increases in the apical cell membrane surface area when experimental animals were subjected to $4 \mathrm{~h}$ of respiratory acidosis $(16,17)$. These changes have been interpreted as consistent with an increased number of proton pumps on the luminal membrane of the intercalated cell $(16,17)$. It has been suggested that this leads to augmented proton secretion by the CCT. Similar findings have been inferred in the turtle bladder and isolated perfused CCT $(12,18)$. Labeling of intracellular acidic compartments with fluorescent probes, demonstrates augmented apical exocytosis in response to isohydric increases in ambient $\mathrm{PCO}_{2}$. However, no measurements of $\mathrm{HCO}_{3}^{-}$flux or proton secretion were made under conditions that examined isolated changes of $\mathrm{PCO}_{2}$ and $\mathrm{pH}$ within the physiologic range.

Recent evidence suggests that the intercalated cell is also responsible for bicarbonate secretion $(17,19)$. It is felt that a subset of intercalated cells secrete $\mathrm{HCO}_{3}^{-}$via apical cell membrane $\mathrm{Cl}-\mathrm{HCO}_{3}^{-}$exchange $(19,20)$. As noted above, in vitro perfused CCTs can secrete and reabsorb $\mathrm{HCO}_{3}^{-}$. It is likely that both processes occur simultaneously and net $\mathrm{HCO}_{3}$ transport is the sum of these two unidirectional fluxes.

To date, net $\mathrm{HCO}_{3}^{-}$transport by the isolated perfused rabbit CCT has been shown to be acutely influenced by transtubular $\mathrm{Cl}^{-}$gradients (21), isoproterenol, and cyclic AMP (10). In addition, antidiuretic hormone has been shown to influence

1. Abbreviations used in this paper: CCT, cortical collecting tubule; PD, potential difference. 
$\mathrm{HCO}_{3}^{-}$transport in the rat CCT (22). Direct acute effects of ambient acid-base conditions on net $\mathrm{HCO}_{3}^{-}$transport in the $\mathrm{CCT}$ remain uncharacterized. This in vitro microperfusion study was therefore designed to examine the effect of acute, in vitro changes in peritubular $\mathrm{HCO}_{3}^{-}$concentration, $\mathrm{pH}$, and $\mathrm{PCO}_{2}$, on net $\mathrm{HCO}_{3}^{-}$transport by the CCT. These changes were designed to mimic the peritubular environment that might bathe the CCT during acute in vivo acid-base disorders. Our findings show that it is primarily peritubular $\mathrm{HCO}_{3}^{-}$concentration but not peritubular $\mathrm{pH}$ or $\mathrm{PCO}_{2}$ which influences net $\mathrm{HCO}_{3}^{-}$transport in the CCT.

\section{Methods}

Female New Zealand white rabbits weighing between 1.5 and $2.0 \mathrm{~kg}$ were killed by decapitation. The left kidney was removed and 1-mmthick coronal slices were made. These were placed in chilled ultrafiltratelike solution containing $5 \% \mathrm{vol} / \mathrm{vol}$ fetal calf serum, $\mathrm{pH}$ 7.4. A slice was transferred in this chilled solution to a dissecting microscope where individual CCTs were freehand dissected with sharpened forceps. The freed segment was then transferred to a thermostatically controlled lucite bath chamber on an inverted microscopic stage. The tubule was cannulated and perfused with concentric micropipettes as previously described (4, $23,24)$. The inner perfusion pipette was advanced 50-100 $\mu \mathrm{m}$ into the tubule lumen and served as a bridge into the tubular lumen to measure transepithelial potential difference (PD, in millivolts). Ringer's agarose bridges were in contact with the perfusate in the rear of the pipette and with the bath solution. Each bridge was, in turn, connected to a calomel half-cell, via a second Ringer's agarose bridge in series with the first. Transepithelial PD was monitored with an electrometer (Keithley Instruments, Inc., Cleveland, $\mathrm{OH}$, model 602) and continuously recorded on a strip chart recorder.

After cannulation bath flow was adjusted to at least $0.5 \mathrm{ml} / \mathrm{min}$ with a Sage infusion pump (Sage Instruments, Cambridge, MA). The bathing solution was warmed to $37^{\circ} \mathrm{C}-38^{\circ} \mathrm{C}$. The perfusion rate was adjusted to between 0.5 and $2.0 \mathrm{nl} / \mathrm{mm} \cdot \mathrm{min}$. The perfusate was collected in a constriction pipette of known volume that ranged between 14.5 and 36 nl. The equilibration period lasted 40-60 min after the bath heat was turned on. The control period was then begun with a measurement of volume flux $\left(J_{\mathrm{V}}\right)$, and then two to four total $\mathrm{CO}_{2}$ flux $\left(\mathrm{J}_{\mathrm{TCO}_{2}}\right)$ determinations were made. After determination of control period $J_{\mathbf{V}}$ and $\mathrm{J}_{\mathrm{TCO}_{2}}$, the bath was changed to one of 10 different experimental solutions. Another $J_{\mathrm{V}}$ determination was made, lasting 10-15 min. Then two to four additional determinations of $\mathrm{J}_{\mathrm{TCO}_{2}}$ were made during the experimental period. These results were also averaged. The perfusate remained unchanged in all of these studies except for the assumed rapid equilibration of the bath and luminal $\mathrm{PCO}_{2}(25)$ when a change in bath $\mathrm{PCO}_{2}$ was made.

\section{Solutions}

In the majority of experiments the tubule was initially perfused and bathed in control solution. The control solution was an artificial ultrafiltrate-like solution with the following composition (in millimolar): $\mathrm{NaCl}$ $105, \mathrm{KCl} 5, \mathrm{NaHCO}_{3} 25, \mathrm{Na}$ acetate $10, \mathrm{NaHPO}_{4} 2.3, \mathrm{CaCL}_{2} 1.8, \mathrm{MgSO}_{4}$ 1 , glucose 8.3 , alanine 5 . The control perfusate and bath were identical except that the bath also contained $5 \% \mathrm{vol} / \mathrm{vol}$ fetal calf serum and the perfusate contained exhaustively dialyzed tritiated inulin as a volume flux marker. Both of these solutions were equilibrated at $37^{\circ} \mathrm{C}$ in $95 \%$ $\mathrm{O}_{2} / 5 \% \mathrm{CO}_{2}$ gas mixture to achieve a $\mathrm{pH}$ of 7.40 .

The effects of ten different experimental conditions on $J_{\mathrm{V}}$ and $\mathbf{J}_{\mathrm{TCO}_{2}}$ were examined. Their composition is shown in Table I. These solutions were designed to examine the effects of three different maneuvers on $\mathrm{CCT} \mathrm{HCO}_{3}^{-}$transport: (a) changing peritubular $\mathrm{HCO}_{3}^{-}$concentration, (b) changing ambient $\mathrm{PCO}_{2},(c)$ isohydric changes in $\mathrm{HCO}_{3}^{-}$concentration and $\mathrm{PCO}_{2}$.

Group 1: effect of peritubular $\mathrm{HCO}_{3}^{-}$concentration. The tubule was equilibrated in the $25 \mathrm{mM} \mathrm{HCO}_{3}^{-}$control bath. Control measurements
Table I. Composition of Solutions

\begin{tabular}{|c|c|c|c|c|c|}
\hline Solutions & pH & $\mathrm{PCO}_{2}$ & $\mathrm{HCO}_{3}^{-}$ & $\mathrm{Cr}^{-}$ & Gluconate \\
\hline & & $m M$ & $m M$ & $m M$ & $m M$ \\
\hline Control & 7.40 & 40 & 25 & 115 & \\
\hline Metabolic acidosis & 6.96 & 40 & 5 & 135 & \\
\hline Metabolic alkalosis & 7.70 & 40 & 50 & 90 & \\
\hline Anion gap acidosis & 7.05 & 40 & 10 & 115 & 15 \\
\hline Cooling control & 7.4 & 40 & 25 & 90 & 25 \\
\hline $\begin{array}{l}\text { Moderate respiratory } \\
\text { acidosis }\end{array}$ & 7.10 & 80 & 25 & 115 & \\
\hline $\begin{array}{l}\text { Severe respiratory } \\
\text { acidosis }\end{array}$ & 6.90 & 120 & 25 & 115 & \\
\hline $\begin{array}{l}\text { Moderate respiratory } \\
\text { alkalosis }\end{array}$ & 7.80 & 14 & 25 & 115 & \\
\hline $\begin{array}{l}\text { Severe respiratory } \\
\text { alkalosis }\end{array}$ & 8.1 & 8 & 25 & 115 & \\
\hline Isohydric elevation & & & & & \\
\hline $\mathrm{CO}_{2}$ and $\mathrm{HCO}_{3}^{-}$ & 7.4 & 80 & 50 & 90 & \\
\hline Isohydric decrease & & & & & \\
\hline $\mathrm{CO}_{2}$ and $\mathrm{HCO}_{3}^{-}$ & 7.4 & 18 & 10 & 130 & \\
\hline
\end{tabular}

The composition of the constituents of the bathing solutions (in millimolar) which were changed in each experimental group are listed. All solutions also contained (in millimolar): $\mathrm{Na}^{+} 145, \mathrm{~K}^{+} 5, \mathrm{Mg}^{2+} 1$, acetate -10 , glucose 8 , alanine $5, \mathrm{HPO}_{4}^{2-} 2.3$, and $\mathrm{Ca}^{2+} 1.8$. The bath also contained $5 \% \mathrm{vol} / \mathrm{vol}$ fetal calf serum while the perfusate contained exhaustively dialyzed inulin.

were made, and then the bath was changed to either the 5,10 , or 50 $\mathrm{mM} \mathrm{HCO}-$-containing bath. Changes in peritubular $\mathrm{HCO}_{3}^{-}$concentration were achieved by reciprocally changing peritubular $\mathrm{Cl}^{-}$concentration except in the $10 \mathrm{mM} \mathrm{HCO}_{3}^{-}$experiment where the peritubular $\mathrm{HCO}_{3}^{-}$ concentration was lowered by replacement with gluconate. This latter group of experiments was designed to measure the effect of peritubular $\mathrm{HCO}_{3}^{-}$concentration in the absence of transtubular $\mathrm{Cl}^{-}$concentration gradients.

The contribution of passive movement of $\mathrm{HCO}_{3}^{-}$down a concentration gradient across the CCT was also examined. In this study the control solutions were symmetrical $25 \mathrm{mM} \mathrm{HCO}_{3}^{-}$-containing solutions, which were identical to the previous control solutions except that $25 \mathrm{mM}$ of $\mathrm{Cl}^{-}$were replaced with gluconate so the control bath and perfusate $\mathrm{Cl}^{-}$ concentration were $90 \mathrm{mM}$. This allowed us to impose a $25 \mathrm{mM}$ bath to lumen $\mathrm{HCO}_{3}^{-}$gradient without imposing any $\mathrm{Cl}^{-}$gradient. In this protocol we first measured $\mathrm{J}_{\mathrm{TCO}_{2}}$ at $37^{\circ} \mathrm{C}$. The bath was then cooled to $20^{\circ} \mathrm{C}$ using a water-jacketed bath line. $\mathrm{J}_{\mathrm{TCO}_{2}}$ was again measured. Finally, the bath was changed to a $50 \mathrm{mM} \mathrm{HCO}-, \mathrm{PCO}_{2} 40, \mathrm{pH} 7.70$ solution identical to the metabolic alkalosis bath but at $20^{\circ} \mathrm{C}$. $\mathrm{J}_{\mathrm{TCO}}$ was again measured. In all of these experiments the liquid junction potential was measured as $<0.5 \mathrm{mV}$. This correction did not significantly change the results of the transepithelial PD and so was discounted.

Group 2: effects of changing ambient $\mathrm{PCO}_{2}$. In addition to the control $\mathrm{PCO}_{2}$ of $40 \mathrm{mmHg}$, we varied ambient $\mathrm{PCO}_{2}$ from values as low as 8 $\mathrm{mmHg}$ up to $120 \mathrm{mmHg}{ }^{2}$ Ambient $\mathrm{pH}$ was allowed to vary.

Group 3: isohydric changes in ambient $\mathrm{PCO}_{2}$ and $\mathrm{HCO}_{3}^{-}$concentration. These studies examined the effect of changing the $\mathrm{PCO}_{2}$ and $\mathrm{HCO}_{3}^{-}$con-

2. Previous studies (23) have verified a close correlation between syringe bath $\mathrm{pH}$ and the $\mathrm{pH}$ of the bath reaching the tubule at $\mathrm{PCO}_{2}$ tensions of 15-74. In preliminary studies using $\mathrm{pH}$ microelectrodes in the bath we also verified that the $\mathrm{pH}$ of the $120 \mathrm{mmHg} \mathrm{PCO}_{2}$ bath reaching the tubule (at $37^{\circ} \mathrm{C}$ ) was at least as acid as that in the syringe (bath $\mathrm{pH} 0.07$ lower than syringe). This shows that there is no detectable loss of $\mathrm{CO}_{2}$ between the syringe and the tubule. 
centration simultaneously so that bath $\mathrm{pH}$ did not vary: In this group bath $\mathrm{HCO}_{3}^{-}$concentration was changed by reciprocally altering $\mathrm{Cl}^{-}$concentration. In the control period the bath, as usual, contained $25 \mathrm{mM}$ $\mathrm{HCO}_{3}^{-}, \mathrm{PCO}_{2} 40 \mathrm{mmHg}, \mathrm{pH} 7.40$. The experimental solutions examined either an isohydric increase in $\mathrm{HCO}_{3}^{-}$concentration $\left(50 \mathrm{mM}, \mathrm{PCO}_{2} 80\right.$, $\mathrm{pH} 7.40)$ or an isohydric decrease in $\mathrm{HCO}_{3}^{-}$concentration $\left(10 \mathrm{mM}, \mathrm{PCO}_{2}\right.$ $18 \mathrm{mmHg}, \mathrm{pH} 7.40$ ).

\section{Microassays}

Net volume flux $\left(J_{v}\right)$ was determined from changes in the $\left[{ }^{3} \mathrm{H}\right]$ inulin activity between the collected fluid and the perfusate as previously described $(24,26,27)$. This was used predominantly to rule out any bulk leak of fluid across the tubule or any significant water flux. Any tubule with a $J_{\mathrm{v}}$ greater than $\pm 0.05 \mathrm{nl} / \mathrm{mm} \cdot \min$ was discarded.

$\mathrm{J}_{\mathrm{TCO}_{2}}$ was determined by microcalorimetry (28) and calculated according to the equation: $\mathrm{J}_{\mathrm{TCO}_{2}}=\left\{\left[\mathrm{CO}_{2}\right]_{\text {in }}-\left[\mathrm{CO}_{2}\right]_{\text {out }}\right\} \cdot V_{0} / \mathrm{min} \cdot 1 /$ length $(\mathrm{mm}) . V_{0} / \mathrm{min}$ equals the rate the perfusate was collected. This equation assumes negligible change in $\mathrm{HCO}_{3}^{-}$concentration due to water flux (as excluded by the $J_{\mathrm{V}}$ determinations). Samples were injected immediately after collection into concentrated sulfuric acid in the picapnotherm chamber (University of California Research Dept.). This value was then compared to a paired injection of the $25 \mathrm{mM} \mathrm{Na}_{2} \mathrm{CO}_{3}$ standard. The $\mathbf{J}_{\mathrm{TCO}_{2}}$ measurements for each period were averaged and this value represents one data point in each individual experiment. At the end of each experiment the tubule was released and the perfusion pipette was advanced directly into a collection pipette. The perfusate total $\mathrm{CO}_{2}\left(\mathrm{TCO}_{2}\right)$ and $\left[{ }^{3} \mathrm{H}\right]$ inulin content were then assayed using the same constant volume pipette as used during the experiment. The perfusate $\mathrm{TCO}_{2}$ was measured two to four times and the values averaged. The measured $\mathrm{TCO}_{2}$ was the value used for $\left[\mathrm{CO}_{2}\right]_{\text {in }}$. The calibration performed at the end of each experiment was assayed for internal variation. The mean standard deviation was $0.8 \mathrm{mM}$. The average number of measurements made was 3.26 per each experimental period. Thus. the accuracy of each average $\mathrm{TCO}_{2}$ collection per period is $0.8 \mathrm{mM} / \sqrt{3.26}$ (i.e., standard error of the mean) or $0.44 \mathrm{mM}$ (29). Thus, we could reliably determine differences of $0.88 \mathrm{mM} \mathrm{TCO}_{2}$ between experiment periods.

In those experiments where ambient $\mathrm{PCO}_{2}$ was altered, the $\mathrm{TCO}_{2}$ of the collected perfusate was corrected for the contribution that the change in $\mathrm{PCO}_{2}$ would theoretically make in measured total $\mathrm{CO}_{2}$. Thus if the

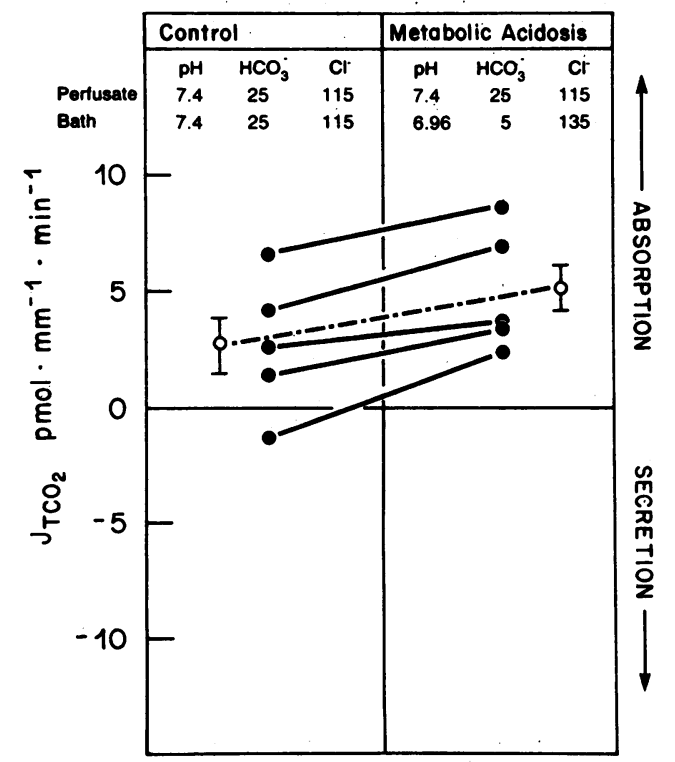

Figure 1. In vitro peritubular metabolic acidosis increases net $\mathrm{HCO}_{3}^{-}$ absorption in the CCT. Individual tubules $(n=5)(\bullet)$. Mean $\mathrm{J}_{\mathrm{TCO}_{2}} \pm \mathrm{SE}$ in $\mathrm{pmol} / \mathrm{mm} \cdot \min (0)$. Control $2.8 \pm 1.3$ vs. experimental $5.1 \pm 1.2$, $P<0.02$.
$\mathrm{PCO}_{2}$ of the bath was raised from 40 to $80 \mathrm{mmHg}$ between control and experimental periods the $\mathrm{TCO}_{2}$ of the collected perfusate would be expected to increase $0.03 \cdot \mathrm{PCO}_{2}(\mathrm{mmHg})$ or, in this case, $1.2 \mathrm{mM}$. Therefore, $1.2 \mathrm{mM}$ was subtracted from the measured $\mathrm{TCO}_{2}$ in each of the experimental period collections. Because there is some loss of $\mathrm{CO}_{2}$ into the oil in the collection pipette this correction tends to slightly overestimate increases in $\mathrm{HCO}_{3}^{-}$absorption and underestimate increases in $\mathrm{HCO}_{3}^{-}$ secretion. ${ }^{3}$

In studies with two periods the $\mathbf{J}_{\mathrm{TCO}_{2}}$ for each tubule was compared between periods by a two-tailed, paired Student's $t$ test. For those experiments where three periods were examined, comparison was made by analysis of variance. $P$ values $<0.05$ were considered significant.

\section{Results}

Effect of changing peritubular $\mathrm{HCO}_{3}^{-}$concentration. The peritubular environment during acute metabolic acidosis was simulated by lowering peritubular $\mathrm{pH}$ from 7.4 to 6.96 and the bath $\mathrm{HCO}_{3}^{-}$concentration from 25 to $5 \mathrm{mM}$. Bath $\mathrm{HCO}_{3}^{-}$was replaced milliequivalent for milliequivalent with $\mathrm{Cl}^{-}$. The control perfusion rate was $1.72 \pm 0.10 \mathrm{nl} / \mathrm{mm} \cdot \min$ and $1.53 \pm 0.07 \mathrm{nl} /$ $\mathrm{mm} \cdot \mathrm{min}$ in the experimental period $(P=0.10, \mathrm{NS})$. In five tubules averaging $1.74 \pm 0.14 \mathrm{~mm}$ in length, the average transepithelial PD was $-22.6 \pm 3.8 \mathrm{mV}$ during the control period and $-21.6 \pm 3.9 \mathrm{mV}$ during the experimental period $(P>0.60, \mathrm{NS})$. The mean $\mathrm{J}_{\mathrm{TCO}_{2}}$ was $2.8 \pm 1.3 \mathrm{pmol} / \mathrm{mm} \cdot \min$ during the control vs. $5.1 \pm 1.2 \mathrm{pmol} / \mathrm{mm} / \mathrm{min}$ during the experimental period $(P$ $<0.02$ ) (Fig. 1, Table I). Thus lowering the peritubular $\mathrm{HCO}_{3}^{-}$ and $\mathrm{pH}$ significantly stimulates $\mathrm{HCO}_{3}^{-}$absorption in the CCT.

We also attempted to simulate the peritubular environment during acute metabolic alkalosis by raising the peritubular $\mathrm{HCO}_{3}^{-}$concentration from 25 to $50 \mathrm{mM}$, raising $\mathrm{pH}$ from 7.4 to 7.7. Control and experimental period perfusion rates were

3. Preliminary experiments documented loss of $\mathrm{CO}_{2}$ into the oil phase with time; previous work (26) has shown that the correction for $\mathrm{PCO}_{2}$ between 14 and $40 \mathrm{mmHg}$ is correct; that the correction for $\mathrm{PCO}_{2}$ between 40 and $80 \mathrm{mmHg}$ is off by only $0.4 \mathrm{mM}$; and that the use of $\mathrm{CO}_{2-}$ equilibrated oil retards the loss of $\mathrm{CO}_{2}$ from the collected perfusate. In the group of experiments examining the effect of $120 \mathrm{mmHg} \mathrm{PCO}_{2}$ we used mineral oil equilibrated with $5 \%$ and $15 \% \mathrm{CO}_{2}$ behind the collected perfusate during control and experimental periods, respectively. The increase in $\mathrm{TCO}_{2}$ owing to the increase in dissolved $\mathrm{CO}_{2}$ was also directly measured. This measurement was performed at the end of each experiment by inhibiting active transport. We achieved this by bathing the tubule in $10^{-4} \mathrm{M}$ acetazolamide and rapidly perfusing the tubule. Acetazolamide inhibits active transport of $\mathrm{HCO}_{3}^{-}$in this segment $(8,9)$ and rapid perfusion makes any potential residual active transport of $\mathrm{HCO}_{3}^{-}$ in this segment, undetectable (4). Cooling could not be used to inhibit transport in this case because it would change the solubility of $\mathrm{CO}_{2}$ in oil and aqueous phase. We documented the inhibition of active transport by this technique by comparing the $\mathrm{TCO}_{2}$ collected from a tubule treated in this manner (in a $\mathrm{PCO}_{2}$ of $40 \mathrm{mmHg}$ ) and the $\mathrm{TCO}_{2}$ collected directly from the perfusion pipette. No difference was found.

After rapidly filling the collection pipette with a volume of perfusate roughly equal to the sample pipette volume, the perfusate was allowed to sit in the collection pipette at $37^{\circ} \mathrm{C}$ for $10 \mathrm{~min}$ (the average collection time). The collected $\mathrm{TCO}_{2}$ was then measured. The difference in $\mathrm{TCO}_{2}$ measured when the acetazolamide-treated tubule was perfused with an ambient $\mathrm{PCO}_{2}$ of 120 vs. $40 \mathrm{mmHg}$, averaged $2.0 \mathrm{mM}$. This number was used to correct for the contribution that difference in dissolved $\mathrm{CO}_{2}$ makes to the change in $\mathrm{TCO}_{2}$ collected during each period. Correction of the measured collected $\mathrm{TCO}_{2}$, for the theoretical contribution that titration of $\mathrm{HCO}_{3}^{-}$by luminal phosphate makes to $\mathrm{TCO}_{2}$, does not change the statistical significance of our data. 


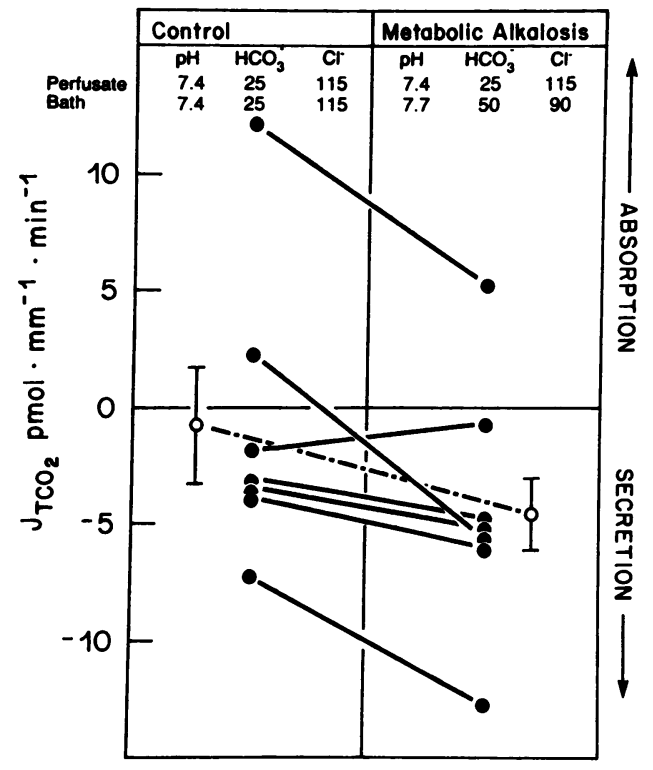

Figure 2. In vitro peritubular metabolic alkalosis inhibits net $\mathrm{HCO}_{3}^{-}$ absorption in the CCT. Individual tubules $(n=7)(\bullet)$. Mean $\mathrm{J}_{\mathrm{TCO}_{2}} \pm \mathrm{SE}$ in $\mathrm{pmol} / \mathrm{mm} \cdot \min (0)$. Control $-0.7 \pm 2.4$ vs. experimental $-4.5 \pm 1.4$, $P<0.05$

$1.92 \pm 0.34$ and $1.98 \pm 0.23 \mathrm{nl} / \mathrm{mm} \cdot \mathrm{min}$, respectively, $(P=0.59$, NS). The average PD during the control period was $-17.6 \pm 5.9$ $\mathrm{mV}$ and $-18.4 \pm 6.0(P>0.60, \mathrm{NS})$ during the experimental period. Fig. 2 and Table II show the results for seven tubules with a length of $2.15 \pm 0.17 \mathrm{~mm}$. Net $\mathrm{HCO}_{3}^{-}$secretion was stimulated or absorption inhibited by raising peritubular $\mathrm{HCO}_{3}^{-}$concentration (control $-0.7 \pm 2.4$ vs. experimental $-4.5 \pm 1.4 \mathrm{pmol} /$ $\mathrm{mm} \cdot \mathrm{min}, P<0.05$ ). Thus metabolic alkalosis stimulates net $\mathrm{HCO}_{3}^{-}$secretion in the CCT.

Because in both of these experiments transtubular $\mathrm{Cl}^{-}$as well as $\mathrm{HCO}_{3}^{-}$concentration gradients existed, we examined the effect of lowering the bath $\mathrm{HCO}_{3}^{-}$concentration without simultaneously imposing a $\mathrm{Cl}^{-}$gradient (Fig. 3, Table II). Peritubular $\mathrm{HCO}_{3}^{-}$concentration was lowered to $10 \mathrm{mM}$ by replacement with gluconate. This study simulates the peritubular environment during an acute anion gap acidosis. The $\mathrm{pH}$ was 7.4 during the control period and 7.05 during the experimental period. Control and experimental period perfusion rates were $0.85 \pm 0.08$ and $0.84 \pm 0.08 \mathrm{nl} / \mathrm{mm} \cdot \mathrm{min}$, respectively $(P=0.84, \mathrm{NS})$. The mean PD during the control period was $-14.1 \pm 4.5$ vs. $-17 \pm 6.8 \mathrm{mV}$ during the experimental period $(P>0.40, N S)$. Fig. 3 shows the results for 10 tubules averaging $2.13 \pm 0.12 \mathrm{~mm}$ in length. Net $\mathrm{HCO}_{3}^{-}$absorption increased in the period of "anion gap acidosis" as compared with the control period (control $2.21 \pm 0.74 \mathrm{pmol} /$ $\mathrm{mm} \cdot \mathrm{min}$ vs. experimental $4.38 \pm 0.66 \mathrm{pmol} / \mathrm{mm} \cdot \mathrm{min}, P$ $<0.0005$ ).

This group also contains a time control because in six tubules the sequence of bath change was from control to experimental and in four tubules this sequence was reversed. In the six tubules changing from control to experimental mean $\mathrm{J}_{\mathrm{TCO}_{2}}$ increased from $2.12 \pm 1.22$ to $4.38 \pm 0.86 \mathrm{pmol} / \mathrm{mm} \cdot \min (P<0.005)$. The change in $\mathrm{J}_{\mathrm{TCO}_{2}}$ in the four experimental-to-control tubules was $4.40 \pm 1.07$ to $2.35 \pm 0.61 \mathrm{pmol} / \mathrm{mm} \cdot \min (P<0.05)$. These results show that changes in peritubular $\mathrm{HCO}_{3}^{-}$and $\mathrm{pH}$ can modulate $\mathrm{HCO}_{3}^{-}$transport in the isolated perfused $\mathrm{CCT}$. Furthermore these effects are not dependent on accompanying changes in peritubular $\mathrm{Cl}^{-}$concentration.

To determine if the passive flux of $\mathrm{HCO}_{3}^{-}$down its concentration gradient could contribute to our results, we cooled the tubule to $20^{\circ} \mathrm{C}$ and then measured net $\mathrm{HCO}_{3}^{-}$transport before and after imposing a $25 \mathrm{mM} \mathrm{HCO}_{3}^{-}$gradient from bath to lumen (Fig. 4, Table II). No transepithelial $\mathrm{Cl}^{-}$gradient existed in these experiments. In the first period net $\mathrm{HCO}_{3}^{-}$transport was measured at $37^{\circ} \mathrm{C}$. The perfusion rate was unchanged between periods (control $0.59 \pm 0.09$, experimental $0.56 \pm 0.06$, recovery $0.59 \pm 0.03 \mathrm{nl} / \mathrm{mm} \cdot \mathrm{min})$. In four tubules with a mean length of $2.41 \pm 0.06 \mathrm{~mm}$, control PD averaged $-12.0 \pm 6.4 \mathrm{mV}$ and $\mathrm{J}_{\mathrm{TCO}_{2}}$ was $1.32 \pm 0.40 \mathrm{pmol} / \mathrm{mm} \cdot \mathrm{min}$. The tubules were then cooled to $20^{\circ} \mathrm{C}$. PD fell to $-5.3 \pm 3.4 \mathrm{mV}$ (control vs. experimental, $P>0.10, \mathrm{NS}$ ) and $\mathrm{J}_{\mathrm{TCO}_{2}}$ fell to $-0.10 \pm 0.31 \mathrm{pmol} /$ $\mathrm{mm} \cdot \mathrm{min}$, a value not statistically different from 0 . The peritubular $\mathrm{HCO}_{3}^{-}$concentration was then increased from 25 to 50 $\mathrm{mM}$ by reciprocal replacement of bath gluconate. The mean PD depolarized slightly more to $1.25 \pm 1.3 \mathrm{mV}[P>0.10$ compared with both control and experimental periods, (NS)]. The mean $\mathrm{J}_{\mathrm{TCO}_{2}}$ was unchanged $(0.20 \pm 0.14 \mathrm{pmol} / \mathrm{mm} \cdot \mathrm{min}, P>0.30$ compared with previous period). Thus, there is no change in $\mathrm{J}_{\mathrm{TCO}_{2}}$ when a $25 \mathrm{mM}$ bath to lumen $\mathrm{HCO}_{3}^{-}$gradient is imposed on CCTs in which active transport is inhibited by cooling to $20^{\circ} \mathrm{C}$.

Effect of changing ambient $\mathrm{PCO}_{2}$. In experiments designed to simulate acute respiratory acid-base disorders, the bath $\mathrm{PCO}_{2}$ and $\mathrm{pH}$ were altered. Two different degrees of acute in vitro respiratory acidosis and respiratory alkalosis were studied.

Ambient pH was lowered from 7.4 to 7.05 by raising the ambient $\mathrm{PCO}_{2}$ from 40 to $80 \mathrm{mmHg}$ (Fig. 5, Table II). Control and experimental period perfusion rates were $1.06 \pm 0.08$ and $1.09 \pm 0.04 \mathrm{nl} / \mathrm{mm} \cdot \mathrm{min}$, respectively $(P=0.61, \mathrm{NS})$. In six tubules with a mean length of $2.06 \pm 0.14 \mathrm{~mm}$, the PD averaged $-31.7 \pm 4.3 \mathrm{mV}$ during the control period and $-29.8 \pm 3.9 \mathrm{mV}$ during the period of hypercapnea $(P>0.60, \mathrm{NS})$. The mean $\mathrm{J}_{\mathrm{TCO}_{2}}$ during the control period was $1.44 \pm 0.74 \mathrm{pmol} / \mathrm{mm} / \mathrm{min}$ and $2.36 \pm 1.50 \mathrm{pmol} / \mathrm{mm} / \mathrm{min}$ during the experimental period. This difference was not statistically significant $(P>0.40)$. Thus, doubling the $\mathrm{PCO}_{2}$ and lowering the $\mathrm{pH}$ had no effect on net $\mathrm{HCO}_{3}^{-}$transport.

Micropuncture studies in the rat have shown that during acute in vivo respiratory acidosis renal cortical $\mathrm{PCO}_{2}$ may be as much as $50 \mathrm{mmHg}$ greater than the arterial $\mathrm{PCO}_{2}$ (30). Renal cortical $\mathrm{PCO}_{2}$ in the rabbit has also been found to be roughly 20 mmHg higher than arterial $\mathrm{PCO}_{2}$ under eucapneic conditions (31). Furthermore, a variety of studies suggest that acute in vivo respiratory acidosis stimulates $\mathrm{HCO}_{3}^{-}$absorption in the distal nephron and CCT in particular $(3,17)$.

It is possible that doubling the bath $\mathrm{PCO}_{2}$ might be insufficient to evoke a measurable increase in $\mathrm{HCO}_{3}^{-}$absorption. We therefore examined the effect of raising bath $\mathrm{PCO}_{2}$ from 40 to 120 $\mathrm{mmHg}$, on net $\mathrm{TCO}_{2}$ flux in the CCT. The ambient $\mathrm{pH}$ was changed from 7.40 in the control period to 6.92 during the experimental period. In three of five tubules the sequence of bath change was from control to experimental and in two of five tubules it was the reverse. Control and experimental period perfusion rates were $0.90 \pm 0.17$ and $0.87 \pm 0.17 \mathrm{nl} / \mathrm{mm} \cdot \mathrm{min}$ respectively $\left(P=0.82\right.$, NS). The acid, high $\mathrm{PCO}_{2}$ bath consistently depolarized the transepithelial PD. In these five tubules, averaging $2.08 \pm 0.17 \mathrm{~mm}$ in length, the mean $\mathrm{PD}$ in the control bath was $-11.8 \pm 6.8 \mathrm{mV}$ vs. $0.0 \pm 1.5 \mathrm{mV}$ in the high $\mathrm{PCO}_{2}$ bath 


\begin{tabular}{|c|c|c|c|c|c|c|}
\hline & & $n$ & Perfusion rate & Perfusate $\mathrm{TCO}_{2}$ & Collected $\mathrm{TCO}_{2}$ & $J_{\text {ToOn }}$ \\
\hline & & & $\mathrm{nl} / \mathrm{mm} \cdot \min$ & $m M$ & $m M$ & $\mathrm{pmol} / \mathrm{mm} \cdot \min$ \\
\hline \multirow[t]{2}{*}{ Metabolic acidosis } & $\mathrm{C}$ & 5 & $1.72 \pm 0.10$ & $23.8 \pm 0.35$ & $22.0 \pm 0.75$ & $2.8 \pm 1.37$ \\
\hline & $\mathbf{E}$ & & $1.53 \pm 0.07$ & & $20.4 \pm 0.78$ & $5.1 \pm 1.2]$ \\
\hline \multirow[t]{2}{*}{ Metabolic alkalosis } & $\mathrm{C}$ & 7 & $1.92 \pm 0.34$ & $23.3 \pm 0.41$ & $24.1 \pm 0.97$ & $-0.7 \pm 2.4 \neg$. \\
\hline & $\mathbf{E}$ & & $1.98 \pm 0.23$ & & $25.9 \pm 0.94$ & $-4.5 \pm 1.4\rfloor$ \\
\hline \multirow[t]{2}{*}{ Anion gap acidosis } & C & 10 & $0.85 \pm 0.08$ & $24.8 \pm 1.05$ & $21.7 \pm 1.36$ & $2.21 \pm 0.7\urcorner$ \\
\hline & $\mathbf{E}$ & & $0.84 \pm 0.08$ & & $18.7 \pm 1.15$ & 4.38 \\
\hline \multirow[t]{3}{*}{$21^{\circ} \mathrm{C}$ high $\mathrm{HCO}_{3}^{-}$} & $\mathrm{C}$ & 4 & $0.59 \pm 0.09$ & $25.2 \pm 0.36$ & $23.0 \pm 0.71$ & $1.32 \pm 0.4$ \\
\hline & $\mathbf{E}$ & & $0.56 \pm 0.06$ & & $25.1 \pm 0.45$ & $-0.10 \pm 0.3$ \\
\hline & $\mathbf{R}$ & & $0.59 \pm 0.03$ & & $25.2 \pm 0.33$ & $0.20 \pm 0.1$ \\
\hline \multirow[t]{2}{*}{ Moderate respiratory acidosis } & C & 6 & $1.06 \pm 0.08$ & $24.4 \pm 0.20$ & $22.8 \pm 0.74$ & $1.44 \pm 0.7$ \\
\hline & $\mathbf{E}$ & & $1.06 \pm 0.04$ & & $22.3 \pm 1.15$ & $2.36 \pm 1.5$ \\
\hline \multirow[t]{2}{*}{ Severe respiratory acidosis } & $\mathrm{C}$ & 5 & $0.90 \pm 0.17$ & $25.5 \pm 0.34$ & $25.7 \pm 0.95$ & $-0.96 \pm 1.12$ \\
\hline & $\mathbf{E}$ & & $0.87 \pm 0.17$ & & $25.5 \pm 1.88$ & $-0.86 \pm 1.38$ \\
\hline \multirow[t]{2}{*}{ Moderate respiratory alkalosis } & $\mathrm{C}$ & 7 & $1.07 \pm 0.10$ & $23.9 \pm 0.33$ & $21.0 \pm 0.96$ & $3.11 \pm 1.23$ \\
\hline & $\mathbf{E}$ & & $1.10 \pm 0.12$ & & $20.9 \pm 1.00$ & $3.27 \pm 1.34$ \\
\hline \multirow[t]{3}{*}{ Severe respiratory alkalosis } & $\mathrm{C}$ & 3 & $0.80 \pm 0.11$ & $23.8 \pm 0.33$ & $18.1 \pm 1.99$ & $3.91 \pm 0.717$ \\
\hline & $\mathbf{E}$ & & $0.80 \pm 0.10$ & & $23.2 \pm 0.53$ & $0.30 \pm 0.21$ \\
\hline & $\mathbf{R}$ & & $0.73 \pm 0.05$ & & $20.9 \pm 0.97$ & لـ2.01土0.55 \\
\hline \multirow[t]{3}{*}{ Isohydric increase $\mathrm{HCO}_{3}^{-}$} & C & 5 & $0.93 \pm 0.08$ & $24.3 \pm 0.16$ & $27.4 \pm 0.89$ & $-2.69 \pm 0.83$ \\
\hline & $\mathbf{E}$ & & $1.18 \pm 0.097$ & & $31.0 \pm 1.72$ & $-6.83 \pm 1.317$ \\
\hline & $\mathbf{R}$ & & $0.92 \pm 0.05$ & & $27.2 \pm 0.97$ & $-2.47 \pm 0.79$ \\
\hline \multirow[t]{3}{*}{ Isohydric decrease $\mathrm{HCO}_{3}^{-}$} & $\mathbf{C}$ & 4 & $0.66 \pm 0.13$ & $25.9 \pm 0.23$ & $25.9 \pm 0.79$ & $0.21 \pm 0.577$ \\
\hline & $\mathbf{E}$ & & $0.65 \pm 0.14$ & & $20.0 \pm 1.45$ & $3.39 \pm 0.76$ \\
\hline & $\mathbf{R}$ & & $0.67 \pm 0.08$ & & $22.0 \pm 1.16$ & $2.59 \pm 0.72$ \\
\hline
\end{tabular}

$\mathrm{C}$, control period; E, experimental period; $\mathrm{R}$, recovery period. Values given as mean $\pm \mathrm{SE} . J_{\mathrm{TCO}_{2}}$ is net $\mathrm{TCO}_{2}$ transport. $\quad * P<0.05 . \quad \ddagger P<0.01$. $\S P<0.001$.

( $P>0.10$, NS). Again, as in the study on the effect of raising the ambient $\mathrm{PCO}_{2}$ to $80 \mathrm{mmHg}$, no significant change in $\mathrm{J}_{\mathrm{TCO}_{2}}$ was observed between the periods of eucapnea and hypercapnea to $120 \mathrm{mmHg}$ (Fig. 6, Table II). The mean $\mathrm{J}_{\mathrm{TCO}_{2}}$ was $-0.96 \pm 1.12$ $\mathrm{pmol} / \mathrm{mm} \cdot \mathrm{min}$ during control and $-0.86 \pm 1.38 \mathrm{pmol} / \mathrm{mm} \cdot \mathrm{min}$ during the experimental period. Analysis of the pooled data for both groups $(n=11)$ studying the effect of hypercapnea on $\mathbf{J}_{\mathrm{TCO}_{2}}$ also failed to reveal a significant effect of this maneuver $(P>0.40)$. Thus, acidosis due to hypercapnea does not stimulate $\mathrm{HCO}_{3}^{-}$absorption in the isolated perfused CCT.

Moderate in vitro respiratory alkalosis was also studied (Fig. 7, Table II). The ambient $\mathrm{PCO}_{2}$ was lowered from 40 to $14 \mathrm{mmHg}$ and bath pH increased from 7.4 to 7.8. Control and experimental period perfusion rates were $1.07 \pm 0.10$ and $1.10 \pm 0.12 \mathrm{nl} /$ $\mathrm{mm} \cdot \mathrm{min}$, respectively $(P<0.82, \mathrm{NS})$. In seven tubules, with a mean length of $1.91 \pm 0.10 \mathrm{~mm}$, the $P D$ was unchanged ( $-20.9 \pm 4.4 \mathrm{mV}$ during control and $-19.7 \pm 3.02 \mathrm{mV}$ during experimental period, $P>0.60$, NS). There was no difference between control $\mathrm{J}_{\mathrm{TCO}_{2}}$ and that observed during hypocapnea being $3.11 \pm 1.23$ vs. $3.27 \pm 1.34 \mathrm{pmol} / \mathrm{mm} \cdot \mathrm{min}$ respectively. Thus, moderate degrees of hypocapnea do not affect $\mathrm{HCO}_{3}^{-}$transport in the CCT.

Because $\mathrm{CO}_{2}$ has been shown to be important to $\mathrm{HCO}_{3}^{-}$ transport in a variety of acidifying epithelia including the CCT and turtle bladder $(11,12,15,24,25,32-34)$, we examined a more severe degree of in vitro respiratory alkalosis to look for an inhibitory effect of hypocapnea on $\mathrm{CCT} \mathrm{HCO}_{3}^{-}$transport. The bath $\mathrm{PCO}_{2}$ was acutely lowered to $8 \mathrm{mmHg}$ (Fig. 8 , Table II).

During acute in vivo respiratory alkalosis in the rat, renal cortical $\mathrm{PCO}_{2}$ was directly measured as $25 \mathrm{mmHg}$ at a time when arterial $\mathrm{PCO}_{2}$ was $15 \mathrm{mmHg}(30)$. Even if an animal could be hyperventilated to an arterial $\mathrm{PCO}_{2}$ of $8 \mathrm{mmHg}$, the renal cortical $\mathrm{PCO}_{2}$ would not be this low. This degree of hypocapnea is thus well outside the physiologic range.

Raising the ambient $\mathrm{pH}$ and lowering the $\mathrm{PCO}_{2}$ to $8 \mathrm{mmHg}$ depolarized the transepithelial PD from $-30.0 \pm 0.0 \mathrm{mV}$ to $-18.5 \pm 1.5 \mathrm{mV}(\mathrm{NS})$. The perfusion rate was unchanged (control $0.80 \pm 0.11$, experimental $0.80 \pm 0.10$, recovery $0.73 \pm 0.05 \mathrm{nl} /$ $\mathrm{mm} \cdot \mathrm{min}, \boldsymbol{P}>0.48$ in all comparisons). In three tubules, with 


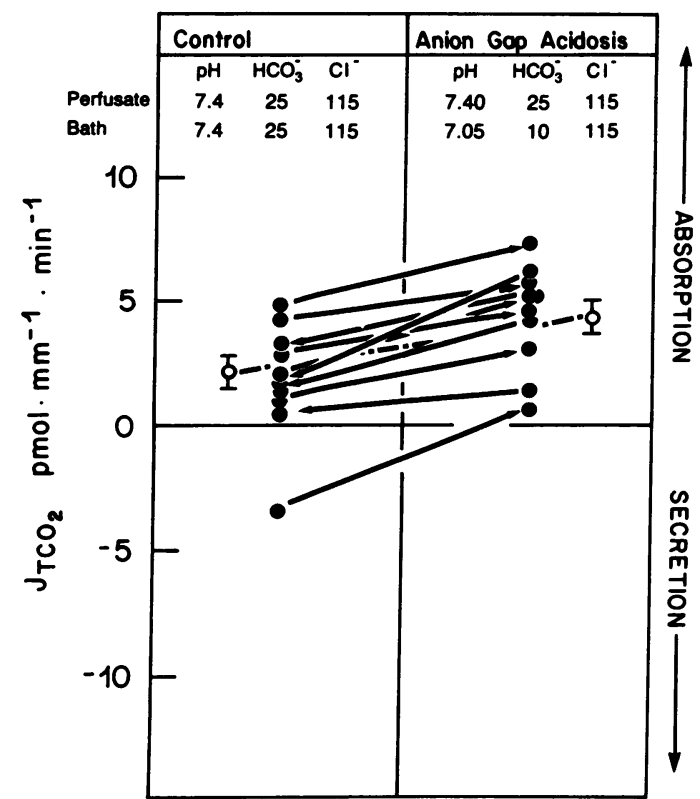

Figure 3. In vitro peritubular anion gap metabolic acidosis stimulates net $\mathrm{HCO}_{3}^{-}$absorption in the $\mathrm{CCT}$. Peritubular $\left[\mathrm{HCO}_{3}^{-}\right]$was lowered by replacing $\mathrm{HCO}_{3}^{-}$with gluconate. Individual tubules $(n=10)(\bullet)$. The arrows indicate the sequence of bath change. Mean $\mathrm{J}_{\mathrm{TCO}_{2}} \pm \mathrm{SE}$ in $\mathrm{pmol} / \mathrm{mm} \cdot \min (\mathrm{O})$. Control $2.21 \pm 0.74$ vs. experimental $4.38 \pm 0.66$, $P<0.0005$.

a mean length of $2.15 \pm 0.05 \mathrm{~mm}$, lowering the $\mathrm{PCO}_{2}$ to $8 \mathrm{mmHg}$ significantly suppressed $\mathrm{HCO}_{3}^{-}$absorption from $3.91 \pm 0.71$ to $0.30 \pm 0.21 \mathrm{pmol} / \mathrm{mm} \cdot \min (P<0.025)$. Return to control bath was associated with partial recovery of $\mathrm{HCO}_{3}^{-}$absorption to

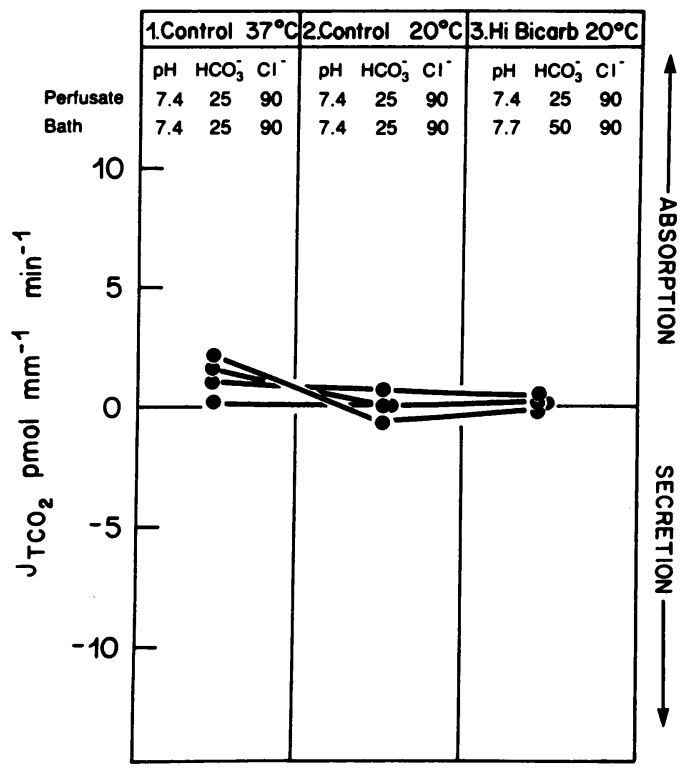

Figure 4. Raising bath $\left[\mathrm{HCO}_{3}^{-}\right]$does not affect net $\mathrm{HCO}_{3}^{-}$transport in tubules cooled to $20^{\circ} \mathrm{C}$. Bath [ $\mathrm{HCO}_{3}^{-}$] was increased without changing $\left[\mathrm{Cl}^{-}\right]$by substituting it for the $25 \mathrm{mM}$ gluconate present in control bath. Individual tubules $(n=4)(\bullet)$. Mean $\mathrm{J}_{\mathrm{TCO}_{2}} \pm \mathrm{SE}$ in pmol/ $\mathrm{mm} \cdot \min$. Period 1, 1.32 \pm 0.40 ; period 2, $-0.10 \pm 0.31$; period 3, $0.20 \pm 0.14$. Period 1 vs. $2 P<0.10$. Period 2 vs. $3 P<0.30$. Period 2 vs. $0 P<0.70$.

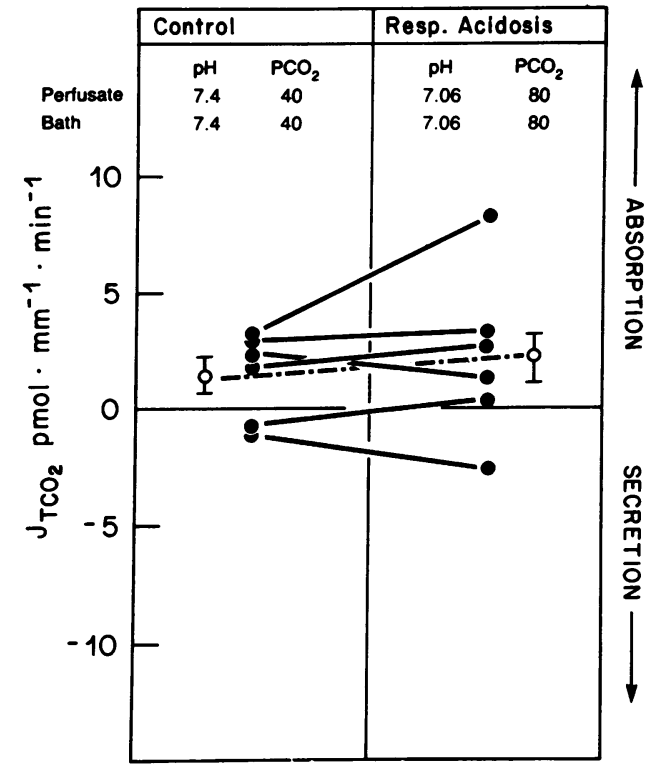

Figure 5. In vitro moderate respiratory acidosis $\left(\mathrm{PCO}_{2}=80 \mathrm{mmHg}\right)$ has no effect on net $\mathrm{HCO}_{3}^{-}$transport in the CCT. Individual tubules $(n=6)(\bullet)$. Mean $\mathrm{J}_{\mathrm{TCO}_{2}} \pm \mathrm{SE}$ in pmol$/ \mathrm{mm} \cdot \min (0)$. Control $1.44 \pm 0.74$ vs. experimental $2.36 \pm 1.50, P>0.40$.

$2.01 \pm 0.55 \mathrm{pmol} / \mathrm{mm} \cdot \mathrm{min}$. This recovery value was statistically different from the control $\mathrm{HCO}_{3}^{-}$flux $(P<0.05)$. Thus, although respiratory acidosis and moderate respiratory alkalosis do not measurably affect $\mathrm{HCO}_{3}^{-}$transport in the CCT, severe reduction of the $\mathrm{PCO}_{2}$ does result in inhibition of $\mathrm{HCO}_{3}^{-}$transport.

Effects of isohydric changes in $\mathrm{PCO}_{2}$ and $\mathrm{HCO}_{3}^{-}$concentration. By simultaneously changing bath $\mathrm{HCO}_{3}^{-}$concentration and $\mathrm{PCO}_{2}$ we were able to vary peritubular $\mathrm{HCO}_{3}^{-}$concentration without

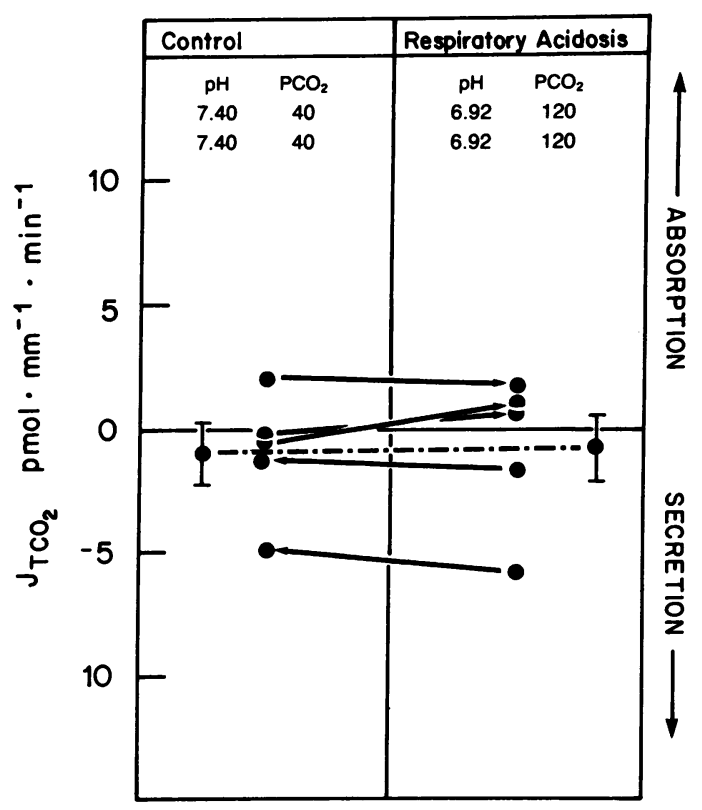

Figure 6. In vitro severe respiratory acidosis $\left(\mathrm{PCO}_{2}=120 \mathrm{mmHg}\right)$ has no effect on net $\mathrm{HCO}_{3}^{-}$transport in the CCT. Individual tubules $(n=5)(\bullet)$. Mean $\mathrm{J}_{\mathrm{TCO}_{2}} \pm \mathrm{SE}$ in $\mathrm{pmol} / \mathrm{mm} \cdot \min (0)$. Control $-0.96 \pm 1.12$ vs. experimental $-0.86 \pm 1.38, P<0.80$. 


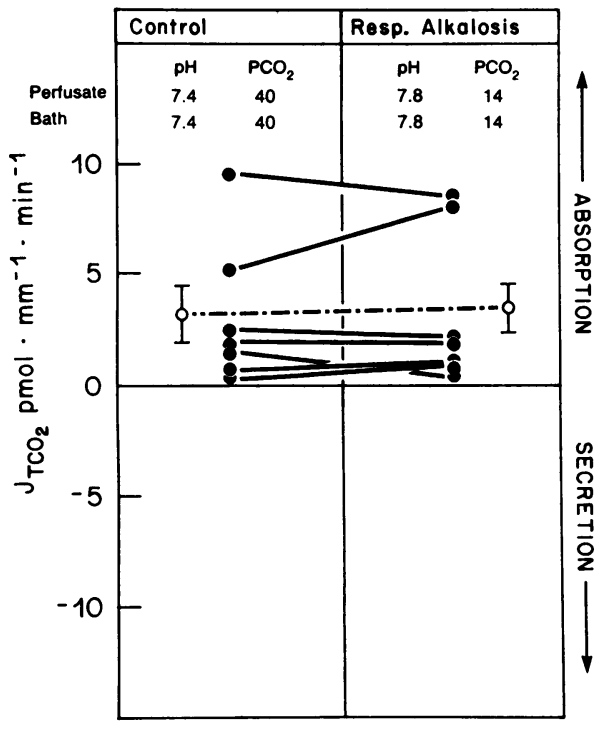

Figure 7. In vitro moderate respiratory alkalosis $\left(\mathrm{PCO}_{2}=14 \mathrm{mmHg}\right)$ has no effect on net $\mathrm{HCO}_{3}^{-}$transport in the CCT. Individual tubules ( $n$ $=7)(\bullet)$. Mean $\mathrm{J}_{\mathrm{TCO}_{2}} \pm \mathrm{SE}$ in $\mathrm{pmol} / \mathrm{mm} \cdot \min (0)$. Control $3.11 \pm 1.23$ vs. experimental $3.26 \pm 1.34, P>0.50$.

varying $\mathrm{pH}$. This maneuver enables one to determine whether the modulation of net $\mathrm{HCO}_{3}^{-}$transport by changes in peritubular $\mathrm{HCO}_{3}^{-}$and/or $\mathrm{Cl}^{-}$concentration was due to the effects of changing the peritubular anion concentrations or due to the accompanying change in $\mathrm{pH}$.

We doubled the peritubular $\mathrm{HCO}_{3}^{-}$concentration replacing $\mathrm{Cl}^{-}$milliequivalent for milliequivalent. The peritubular $\mathrm{pH}$ was maintained constant at 7.40 by simultaneously doubling the ambient $\mathrm{PCO}_{2}$ from 40 to $80 \mathrm{mmHg}$. The perfusion rate was unchanged except between experimental and recovery where there was a statistically significant difference, $P=0.03$ (control $0.93 \pm 0.08$, experimental $1.18 \pm 0.09$, recovery $0.92 \pm 0.05 \mathrm{nl} /$ $\mathrm{mm} \cdot \mathrm{min}$ ). In five tubules averaging $2.17 \pm 0.14 \mathrm{~mm}$, the PD in the control period averaged $-21.7 \pm 4.8 \mathrm{mV}$ vs. $-20.8 \pm 3.9 \mathrm{mV}$ $(P>0.70$, NS) during the experimental period. Doubling the peritubular $\mathrm{HCO}_{3}^{-}$concentration without changing $\mathrm{pH}$ stimulated $\mathrm{HCO}_{3}^{-}$secretion in every case (Fig. 9, Table II). The mean $\mathrm{J}_{\mathrm{TCO}_{2}}$ in the control period was $-2.69 \pm 0.83 \mathrm{pmol} / \mathrm{mm} \cdot \mathrm{min}$ and increased to $-6.83 \pm 1.31 \mathrm{pmol} / \mathrm{mm} \cdot \mathrm{min}$ during the experimental period. This stimulation was fully reversible by returning to the control bath. The change in net $\mathrm{HCO}_{3}^{-}$flux observed with the isohydric increase in peritubular $\mathrm{HCO}_{3}^{-}$concentration was comparable to that observed with nonisohydric changes in bath $\mathrm{HCO}_{3}^{-}$concentration $(\Delta=-4.14$ vs. $-3.80 \mathrm{pmol} / \mathrm{mm} \cdot \mathrm{min})$. Thus, raising bath $\mathrm{HCO}_{3}^{-}$stimulates net $\mathrm{HCO}_{3}^{-}$secretion whether the peritubular $\mathrm{pH}$ increases or remains constant.

The peritubular $\mathrm{HCO}_{3}^{-}$concentration was also isohydrically acutely lowered by replacing $\mathrm{HCO}_{3}^{-}$with $\mathrm{Cl}^{-}$milliequivalent for milliequivalent. The ambient $\mathrm{PCO}_{2}$ was lowered to a value within a range of $\mathrm{PCO}_{2}$ tensions shown, by earlier experiments, not to independently alter net $\mathrm{HCO}_{3}^{-}$transport in the CCT (i.e., $\geqq 14$ $\mathrm{mmHg}$ ). The perfusion rate was unchanged (control $0.66 \pm 0.13$, experimental $0.65 \pm 0.14$, recovery $0.67 \pm 0.08 \mathrm{nl} / \mathrm{mm} \cdot \min , P$ $\geqq 0.84$ in all comparisons). In four tubules, averaging $2.08 \pm 0.17$ $\mathrm{mm}$ in length, the PD in the control period was $-13.3 \pm 3.9 \mathrm{mV}$ vs. a mean PD of $-15.0 \pm 6.9 \mathrm{mV}$ during the experimental period $(P>0.60, \mathrm{NS})$. Isohydrically lowering bath $\mathrm{HCO}_{3}^{-}$concentration to $10 \mathrm{mM}$ and the $\mathrm{PCO}_{2}$ to $18 \mathrm{mmHg}$ significantly stimulated net $\mathrm{HCO}_{3}^{-}$absorption in four of four tubules from a mean $\mathrm{J}_{\mathrm{TCO}_{2}}$ of $0.21 \pm 0.57$ to $3.39 \pm 0.76 \mathrm{pmol} / \mathrm{mm} \cdot \mathrm{min}$ during the experimental period $(P<0.005)$ (Fig. 10, Table II). Changing back to the control bath was associated with a decrease in net $\mathrm{HCO}_{3}^{-}$absorption to $2.59 \pm 0.72 \mathrm{pmol} / \mathrm{mm} \cdot \min (P<0.08)$. This

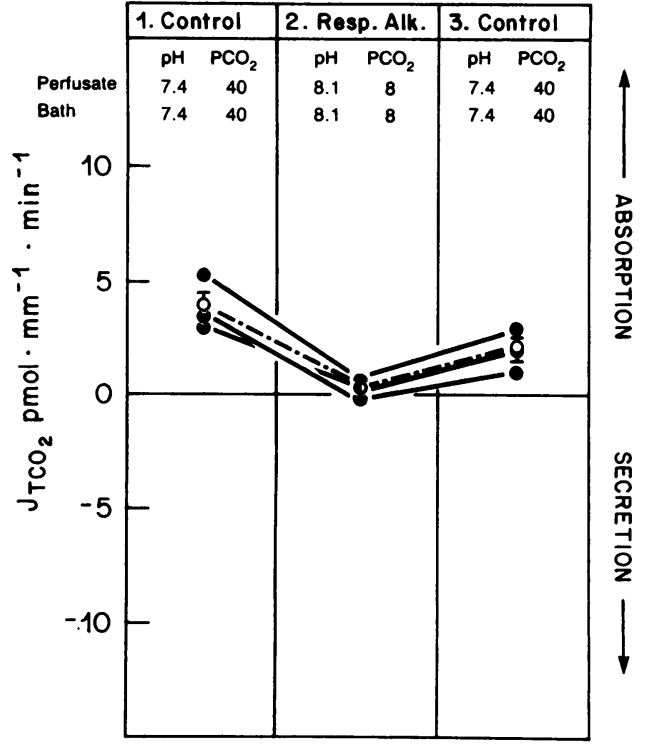

Figure 8. In vitro severe respiratory alkalosis $\left(\mathrm{PCO}_{2}=8 \mathrm{mmHg}\right)$ inhibits net $\mathrm{HCO}_{3}^{-}$absorption in the CCT. Individual tubules $(n=3)(\bullet)$. Mean $\mathrm{J}_{\mathrm{TCO}_{2}} \pm \mathrm{SE}$ in pmol$/ \mathrm{mm} \cdot \min (0)$. Period 1, 3.91 \pm 0.71 ; period 2, $0.30 \pm 0.21$; period $3,2.01 \pm 0.55$; period 1 vs. $2 P<0.01$, period 2 vs. 3 $P<0.05$, period 1 vs. $3 P>0.05$.

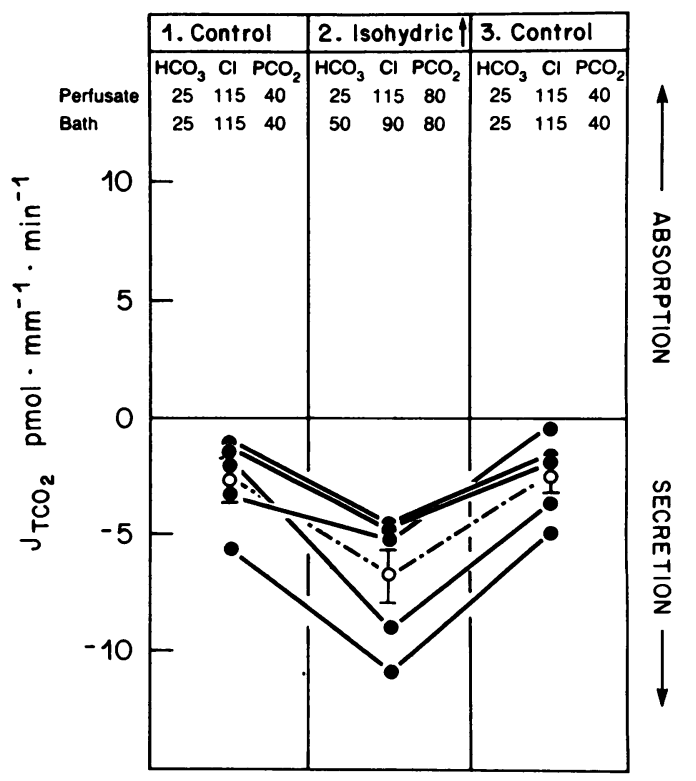

Figure 9. Isohydric increase in bath $\left[\mathrm{HCO}_{3}^{-}\right]$and $\mathrm{PCO}_{2}$ stimulates net $\mathrm{HCO}_{3}^{-}$secretion in the CCT. Individual tubules $(n=5)(\bullet)$. Mean $\mathrm{J}_{\mathrm{TCO}_{2}} \pm \mathrm{SE}$ in $\mathrm{pmol} / \mathrm{mm} \cdot \min (\mathrm{O})$. Period $1,-2.69 \pm 0.83$; period 2, $-6.83 \pm 1.31$; period $3,-2.41 \pm 0.79$, period 1 vs. $2 P<0.01$, period 2 vs. $3 P<0.001$, period 1 vs. $3 P>0.50$. 


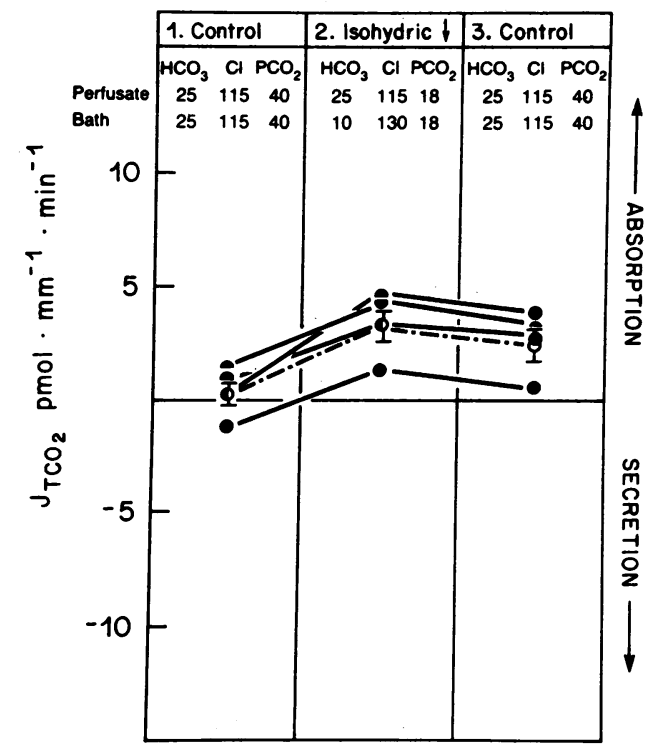

Figure 10. Isohydric decrease in bath $\left[\mathrm{HCO}_{3}^{-}\right]$and $\mathrm{PCO}_{2}$ stimulates net $\mathrm{HCO}_{3}^{-}$absorption in the CCT. Individual tubules $(n=4)(\bullet)$. Mean $\mathrm{J}_{\mathrm{TCO}_{2}} \pm \mathrm{SE}$ in $\mathrm{pmol} / \mathrm{mm} \cdot \min ($ (o). Period $1,-0.21 \pm 0.57$; period 2 , $3.39 \pm 0.76$; period $3,2.59 \pm 0.72$; period 1 vs. $2 P<0.001$, period 2 vs. $3 P<0.08$, period 1 vs. $3 P<0.001$.

recovery was only partial since $\mathrm{J}_{\mathrm{TCO}_{2}}$ was not significantly different from experimental $\mathbf{J}_{\mathrm{TCO}_{2}}$ using analysis of variance. The reason for incomplete recovery is unclear but may be secondary to the small number of tubules in this group. Additionally, recovery may require a longer period of time. Nevertheless, this experiment is consistent with the previous studies and also demonstrates that lowering the bath $\mathrm{HCO}_{3}^{-}$concentration stimulates net $\mathrm{HCO}_{3}^{-}$absorption whether $\mathrm{pH}$ is constant or allowed to fall.

\section{Discussion}

The present studies examine the effect of acute in vitro changes in peritubular $\mathrm{HCO}_{3}^{-}, \mathrm{pH}$, and $\mathrm{PCO}_{2}$ on net $\mathrm{HCO}_{3}^{-}$transport in the CCT. Lowering the peritubular $\mathrm{HCO}_{3}^{-}$and $\mathrm{pH}$ stimulated net $\mathrm{HCO}_{3}^{-}$absorption whereas raising the peritubular $\mathrm{HCO}_{3}^{-}$and pH stimulated net $\mathrm{HCO}_{3}^{-}$secretion. Lowering peritubular $\mathrm{HCO}_{3}^{-}$without changing peritubular $\mathrm{Cl}^{-}$concentration also stimulated $\mathrm{HCO}_{3}^{-}$absorption, showing that alterations in peritubular $\mathrm{Cl}^{-}$concentration were not necessary for this effect. Cooling experiments were performed to show that the passive movement of $\mathrm{HCO}_{3}^{-}$down its concentration gradient does not account for these findings. Changes in ambient $\mathrm{PCO}_{2}$, associated with changes in bath $\mathrm{pH}$ comparable to those studied in the metabolic acid-base disturbance protocols, had no effect on net $\mathrm{HCO}_{3}^{-}$transport by the CCT. Only when the ambient $\mathrm{PCO}_{2}$ was lowered to $\sim 8 \mathrm{mmHg}$ was net $\mathrm{HCO}_{3}^{-}$absorption inhibited. Finally, isohydric increases and decreases in $\mathrm{HCO}_{3}^{-}$concentration demonstrate that changes in peritubular $\mathrm{HCO}_{3}^{-}$but not $\mathrm{pH}$ was the critical parameter modulating net $\mathrm{HCO}_{3}^{-}$transport. In conclusion we find that changes in peritubular $\mathrm{HCO}_{3}^{-}$and $\mathrm{Cl}^{-}$concentration, but not $\mathrm{pH}$ or ambient $\mathrm{PCO}_{2}$ (within the physiologic range), regulate net $\mathrm{HCO}_{3}^{-}$transport in the CCT.

Bicarbonate movement in the CCT is unique in that bidirectional active $\mathrm{HCO}_{3}^{-}$transport exists. McKinney and Burg (5) first demonstrated $\mathrm{HCO}_{3}^{-}$transport in the $\mathrm{CCT}$ and documented that chronic in vivo metabolic alkalosis stimulates net $\mathrm{HCO}_{3}^{-}$ secretion whereas chronic in vivo metabolic acidosis stimulates net $\mathrm{HCO}_{3}^{-}$absorption. Both of these processes are very similar to $\mathrm{HCO}_{3}^{-}$transport mechanisms in the turtle bladder (811, 34-36).

Bicarbonate absorption by both the turtle bladder and the CCT is electrogenic $(6,11,32-35)$. Most data suggest that protons are electrogenically pumped into the lumen by an apical membrane proton translocating adenosine triphosphatase leaving $\mathrm{OH}^{-}$ions in the cell (35-39). Since $\mathrm{HCO}_{3}^{-}$absorption is inhibited by low $\mathrm{CO}_{2}$ tensions and acetazolamide $(8,32-34,36)$ it is likely that the intracellular $\mathrm{OH}^{-}$is carboxylated by $\mathrm{CO}_{2}$, in a carbonic anhydrase facilitated step, to form $\mathrm{HCO}_{3}^{-}$, which then exits the cell. $\mathrm{HCO}_{3}^{-}$absorption is inhibited by the removal of peritubular $\mathrm{Cl}^{-}$so it has been postulated that basolateral $\mathrm{HCO}_{3}^{-}$exit is mediated by a Cl$-/ \mathrm{HCO}_{3}^{-}$exchanger $(40,41)$. Electrochemical gradients for both $\mathrm{HCO}_{3}^{-}$and $\mathrm{Cl}^{-}$may thus influence base exit from the cell.

The mechanism for unidirectional $\mathrm{HCO}_{3}^{-}$secretion is less well established. This process appears to be sodium-independent, insensitive to ouabain, and inhibited by acetazolamide $(9,10$, 20). $\mathrm{HCO}_{3}^{-}$secretion is also inhibited by the removal of luminal $\mathrm{Cl}^{-}$, so that a luminal $\mathrm{Cl}^{-} / \mathrm{HCO}_{3}^{-}$exchanger has been proposed $(10,19,20,42,43)$. It has recently been postulated that a basolateral proton translocating adenosine triphosphatase secretes protons into the peritubular space, raising cell $\mathrm{HCO}_{3}^{-}$concentration, thus driving $\mathrm{HCO}_{3}^{-}$secretion $(19,44)$. The $\mathrm{HCO}_{3}^{-}$secretory cell may then be essentially the same as the $\mathrm{HCO}_{3}^{-}$absorptive cell except that its polarity is reversed. According to this model the $\mathrm{HCO}_{3}^{-}$secretory cell would possess a luminal $\mathrm{Cl}^{-} / \mathrm{HCO}_{3}^{-}$exchanger and basolateral proton pump. This is the inverse of the apical proton pump and basolateral $\mathrm{Cl}^{-} / \mathrm{HCO}_{3}^{-}$ exchanger that has been proposed for the $\mathrm{HCO}_{3}^{-}$absorptive cell. Net $\mathrm{HCO}_{3}^{-}$transport in the CCT is the sum of these two unidirectional processes.

Our studies have demonstrated that changes in peritubular $\mathrm{HCO}_{3}^{-}$and $\mathrm{Cl}^{-}$concentration influence $\mathrm{HCO}_{3}^{-}$transport by the CCT. Transtubular $\mathrm{Cl}^{-}$gradients have been shown to influence net $\mathrm{HCO}_{3}^{-}$secretion (21). Chloride gradients might alter net $\mathrm{HCO}_{3}^{-}$transport in the $\mathrm{CCT}$ by influencing base exit via a $\mathrm{Cl}^{-} / \mathrm{HCO}_{3}^{-}$exchanger which could be located on either the luminal or peritubular membrane. Changes in $\mathrm{Cl}^{-}$concentration gradients across membranes containing a proton pump may also influence the rate of proton pumping. For example, altered $\mathrm{HCO}_{3}^{-}$absorption in the medullary collecting duct has been observed with changes in luminal $\mathrm{Cl}^{-}$concentration (41). Removing luminal $\mathrm{Cl}^{-}$in the medullary collecting duct stimulated $\mathrm{HCO}_{3}^{-}$absorption by $50 \%$. Because this segment only absorbs $\mathrm{HCO}_{3}^{-}(4)$ it is unlikely that inhibition of simultaneous $\mathrm{HCO}_{3}^{-}$ secretion accounts for these observations. It was postulated that the increased bath-to-lumen $\mathrm{Cl}^{-}$gradient enhanced shunting of electrogenic proton secretion. Thus, if the $\mathrm{HCO}_{3}^{-}$secretory cell is in fact the same as the $\mathrm{HCO}_{3}^{-}$absorptive cell, except with reversed polarity, changes in peritubular $\mathrm{Cl}^{-}$concentration may influence both unidirectional $\mathrm{HCO}_{3}^{-}$secretion and unidirectional $\mathrm{HCO}_{3}^{-}$absorption, thereby altering net $\mathrm{HCO}_{3}^{-}$transport. Whatever the mechanism, it is unquestionable that $\mathrm{Cl}^{-}$concentration gradients can influence net $\mathrm{HCO}_{3}^{-}$transport in the CCT.

The changes in peritubular $\mathrm{Cl}^{-}$concentration used in the current study are similar to the changes in peritubular $\mathrm{Cl}^{-}$concentration that would be predicted to occur in vivo during met- 
abolic acid-base disturbances. These gradients are smaller than those studied by Laski et al. (21). As is the case in many metabolic acid-base disorders, our studies reciprocally changed peritubular $\mathrm{Cl}^{-}$concentration and $\mathrm{HCO}_{3}^{-}$concentration. Isolated changes in peritubular $\mathrm{HCO}_{3}^{-}$concentration would be expected to change transcellular $\mathrm{HCO}_{3}^{-}$flux if the above model is correct. Changing the $\mathrm{HCO}_{3}^{-}$concentration would alter the driving force across the $\mathrm{Cl}^{-} / \mathrm{HCO}_{3}^{-}$exchanger in the proton secretory cell and might alter basolateral proton pumping in the $\mathrm{HCO}_{3}^{-}$secretory cell by changing the peritubular $\mathrm{pH}$ and the electrochemical driving force for $\mathrm{H}^{+}$pumping. Because we demonstrate in these studies that lowering the peritubular $\mathrm{HCO}_{3}^{-}$concentration without changing peritubular $\mathrm{Cl}^{-}$concentration stimulates net $\mathrm{HCO}_{3}^{-}$ absorption, our data verifies that $\mathrm{Cl}^{-}$concentration is not the sole factor modulating $\mathrm{HCO}_{3}^{-}$transport in metabolic acid-base disturbances. These findings cannot distinguish this effect as being on unidirectional bicarbonate secretion, unidirectional bicarbonate absorption or both.

We examined the role of passive $\mathrm{HCO}_{3}^{-}$flux down its concentration gradient. Active $\mathrm{HCO}_{3}^{-}$transport was inhibited by cooling the tubule to $20^{\circ} \mathrm{C}$. $\mathrm{A} \mathrm{HCO}_{3}^{-}$concentration gradient was then imposed. The results show no change in $\mathrm{J}_{\mathrm{TCO}_{2}}$ when cooled tubules are exposed to changes in peritubular $\mathrm{HCO}_{3}^{-}$concentration. Under these conditions, in CCTs from unpretreated rabbits, estimated bicarbonate permeability is 0 . Using intracellular microelectrodes, Samsom et al. (45) directly measured anion conductance in the isolated perfused rabbit CCT at $38^{\circ} \mathrm{C}$. They could not detect any $\mathrm{HCO}_{3}^{-}$conductance. Paracellular ionic movement is conductive in nature so the absence of $\mathrm{HCO}_{3}^{-}$conductance in this segment argues strongly against paracellular bicarbonate movement. In accord with these findings are the experiments in which $\mathrm{PCO}_{2}$ was raised to $120 \mathrm{mmHg}$. In these studies a mean voltage drop from -11.8 to $+1.5 \mathrm{mV}$ had no effect on $\mathrm{J}_{\mathrm{TCO}_{2}}$. This is in agreement with the lack of conductive movement of $\mathrm{HCO}_{3}^{-}$in this segment. The lack of an effect of $\mathrm{HCO}_{3}^{-}$concentration gradients in cooled CCTs also argues against passive paracellular movement of $\mathrm{HCO}_{3}^{-}$in the CCT. Hence changes in peritubular $\mathrm{HCO}_{3}^{-}$concentration modulate a transcellular transport process.

The next series of experiments examined the effects of altering ambient $\mathrm{PCO}_{2}$ within the physiologic range. We found no effect of changing $\mathrm{PCO}_{2}$, over a range from 14 to $120 \mathrm{mmHg}$, on net $\mathrm{HCO}_{3}^{-}$transport in the CCT. There are several possible explanations for this lack of an effect of changes in $\mathrm{PCO}_{2}$ and $\mathrm{pH}$ on net bicarbonate transport in the CCT. It is possible that unidirectional bicarbonate secretion and unidirectional bicarbonate absorption may both be simultaneously, symmetrically, stimulated or inhibited by these changes in $\mathrm{PCO}_{2}$. Both net bicarbonate secretion and bicarbonate absorption are inhibited by acetazolamide $(8,9)$. This suggests they may both be dependent on the presence of $\mathrm{CO}_{2}$ and carbonic anhydrase for the formation of $\mathrm{HCO}_{3}^{-}$from intracellular $\mathrm{OH}^{-}$ion and $\mathrm{CO}_{2}$ as outlined previously. The experimental changes in $\mathrm{PCO}_{2}$ would then be expected to symmetrically affect the $\mathrm{CO}_{2}$ availability in both the bicarbonate secretory and bicarbonate absorbing cell.

Alternatively, changes in $\mathrm{PCO}_{2}$ availability may not, in fact, influence either unidirectional $\mathrm{HCO}_{3}^{-}$transport flux. Studies have been performed in the turtle bladder which suggest that unidirectional $\mathrm{H}^{+}$secretion is relatively unaffected by anisohydric changes in $\mathrm{PCO}_{2}$ over a broad range of values. Schwartz (32) measured proton secretion $\left(J_{\mathbf{H}^{+}}\right)$by reverse short circuit current in ouabain-treated turtle bladders under conditions of anisohy- dric increases in serosal $\mathbf{P C O}_{2}$. Although there was a linear increase in reverse short circuit current with increases in $\mathrm{PCO}_{2}$ between 0 and $4.5 \%$, from 4.5 to $20 \% \mathrm{CO}_{2}$ no further increase in reverse short circuit current was observed. Cohen and Steinmetz (33) also found that as $\mathrm{PCO}_{2}$ was increased a plateau in $J_{\mathrm{H}^{+}}$was achieved. The $\mathrm{PCO}_{2}$ at which this plateau was reached, was variable and directly proportional to the serosal $\mathrm{HCO}_{3}^{-}$concentration. This suggests that cell $\mathrm{pH}$ rather than cell $\mathrm{PCO}_{2}$ may be the critical variable. At low $\mathrm{PCO}_{2}$ values, these investigators also observed a linear increase in $J_{\mathbf{H}^{+}}$with increasing $\mathrm{PCO}_{2}$. The slope of this linear increase, decreased as serosal $\mathrm{HCO}_{3}^{-}$concentration was increased. This is consistent with a relationship between cell $\mathrm{pH}$ and $J_{\mathrm{H}^{+}}$in the alkaline range. Cell $\mathrm{pH}$ was measured with DMO. Half-maximal proton secretory rates occurred at an estimated intracellular $\left[\mathrm{H}^{+}\right]$of $25 \mathrm{nM}$ or when cell $\mathrm{pH}$ is about 7.60. Under control conditions (ambient $\mathrm{PCO}_{2}$ of $5 \%$ and $20 \mathrm{mM} \mathrm{HCO}_{3}^{-}$) cell $\mathrm{pH}$ was estimated as 7.28 or a $\left[\mathrm{H}^{+}\right]$of 52 $\mathrm{nM}$. Therefore, the cell is relatively acid under control conditions and control $J_{\mathrm{H}^{+}}$is already at $80 \%$ of maximal rates. Apparently cell $\mathrm{pH}$ becomes a critical determinant of $\mathrm{J}_{\mathrm{H}^{+}}$only when the cell is very alkaline compared with control state. When cell $\left[\mathrm{H}^{+}\right]$ increased from 52 to $186 \mathrm{nM}$ there is only a $20 \%$ additional increase in $J_{\mathrm{H}^{+}}$. In the turtle bladder changes in $\mathrm{PCO}_{2}$ appear to have an affect on $J_{\mathrm{H}^{+}}$only when they make the cell alkaline and do not greatly affect the $J_{\mathrm{H}^{+}}$when raising the ambient $\mathrm{PCO}_{2}$ causes cell $\mathrm{pH}$ to fall below 7.4. Similar studies, examining the relationship between serosal $\mathrm{PCO}_{2}$ and unidirectional bicarbonate secretion have not been performed. Any relationship between serosal $\mathrm{PCO}_{2}$ and $\mathrm{pH}$ on unidirectional bicarbonate secretion remains speculative.

The current studies found no change in net $\mathrm{HCO}_{3}^{-}$absorption when $\mathrm{PCO}_{2}$ was varied between 14 and $120 \mathrm{mmHg}$. Only when the ambient $\mathrm{PCO}_{2}$ was lowered to less than $14 \mathrm{mmHg}$ did net $\mathrm{HCO}_{3}^{-}$transport fall. No increase in $\mathrm{HCO}_{3}^{-}$absorption was found when the ambient $\mathrm{PCO}_{2}$ was doubled or even tripled. These findings are similar to the previous studies cited in so far as a major effect of $\mathrm{PCO}_{2}$ on $\mathrm{HCO}_{3}^{-}$absorption occurs only in the hypocapneic end of the spectrum, i.e., when the cell would be expected to become alkaline. Near-maximal rates of $\mathrm{HCO}_{3}^{-}$transport appear to be achieved at a lower ambient $\mathrm{PCO}_{2}$ than is observed in the turtle bladder. There may be several reasons for these differences including $(a)$ relative insensitivity of the assay (microcalorimetry in the CCT vs. electrically determined proton secretion in turtle bladder), (b) the measurement of net $\mathrm{HCO}_{3}^{-}$ flux vs. unidirectional proton secretion, $(c)$ physiologic differences in the epithelium studied, such as different cell buffering power, different rates of metabolic $\mathrm{CO}_{2}$ production, or differences in substrate affinity of $\mathrm{H}^{+}$or $\mathrm{HCO}_{3}^{-}$transporters. Nevertheless, assuming that cell $\mathrm{pH}$ changes when ambient $\mathrm{PCO}_{2}$ is changed, these studies suggest the same conclusion: cell $\mathrm{pH}$ is probably not a critical regulator of net acidification in the CCT outside of the alkaline range. Under physiologic conditions the regulation of CCT acidification may occur on the plateau portion of the $J_{\mathbf{H}^{+}} /$cell $\mathrm{pH}$ curve where factors other than cell $\mathrm{pH}$ play a predominant role. This conclusion is further strengthened by the finding that the changes in net $\mathrm{HCO}_{3}^{-}$transport induced by isohydric changes in peritubular $\mathrm{HCO}_{3}^{-}$concentration are roughly the same as the effect of nonisohydric changes in peritubular $\mathrm{HCO}_{3}^{-}$concentration. Isohydric changes in peritubular $\mathrm{HCO}_{3}^{-}$ would presumably change cell $\mathrm{pH}$ much less than nonisohydric changes (if at all), yet no discernable difference in $\Delta \mathrm{J}_{\mathrm{TCO}_{2}}$ is seen between these two experimental groups. It seems that $\mathrm{HCO}_{3}^{-}$ 
and $\mathrm{Cl}^{-}$concentration gradients have a much more striking effect on net $\mathrm{HCO}_{3}^{-}$transport than do changes in peritubular $\mathrm{pH}$.

The morphologic studies of Verlander et al. (17) suggest that proton secretion by the rat CCT is stimulated by in vivo respiratory acidosis. These investigators describe two subpopulations of intercalated cells in the rat CCT: a light form with prominent apical microprojections and a dark form with short and sparse apical projections. The light form displayed extensive proliferation of the apical membrane during respiratory acidosis, similar to that observed by Madsen and Tisher (16) in the outer medullary collecting duct of the rat during respiratory acidosis. These changes are consistent with increased insertion of proton pumps on the apical membrane of these cells (16). The authors suggest that the light intercalated cell is responsible for proton secretion (i.e., $\mathrm{HCO}_{3}^{-}$reabsorption) and the dark intercalated cell is responsible for $\mathrm{HCO}_{3}^{-}$secretion. Inasmuch as respiratory acidosis only changed one cell subpopulation, the authors suggest that respiratory acidosis stimulates net $\mathrm{HCO}_{3}^{-}$absorption in the CCT, enhancing urinary acidification. The previously cited studies of Schwartz and Al-Awqati (18) in the isolated perfused CCT also suggest a role for hypercapnea as a stimulus for increased insertion of proton pumps on the apical cell membrane of a subpopulation of intercalated cells in the CCT.

There are several possible explanations for the apparent discrepancy between our findings and these studies. The studies of Verlander, Madsen, and Tisher were on animals with $4 \mathrm{~h}$ of in vivo respiratory acidosis. The time of hypercapnea or any one of several other in vivo perturbations, such as altered catecholamines, or changes in the luminal fluid delivered to the CCT, could be additional important variables.

The studies of Schwartz and Al-Awqati (18) examined simultaneous lumen and bath isohydric increases in $\mathrm{PCO}_{2}$. We examined only peritubular changes in these studies so no direct comparison can be made between the two studies. Small changes in net $\mathrm{HCO}_{3}^{-}$transport might go undetected in our study yet be associated with impressive changes in cell morphology. Even if this were the case one could still conclude that the effects of peritubular $\mathrm{HCO}_{3}^{-}$and $\mathrm{Cl}^{-}$concentration are certainly predominant over those of either peritubular $\mathrm{pH}$ or $\mathrm{PCO}_{2}$. It is also possible that these morphologic changes may, in fact, not be associated with enhanced net urinary acidification by the CCT.

We would like to stress that these studies examined only net $\mathrm{HCO}_{3}^{-}$transport in cortical collecting tubules. In each of the protocols it is impossible to ascribe any significant change in net $\mathrm{HCO}_{3}^{-}$transport to changes in unidirectional proton secretion or $\mathrm{HCO}_{3}^{-}$secretion. Similarly, in protocols in which no effect on net $\mathrm{HCO}_{3}^{-}$transport was observed it is possible that significant but cancelling effects on unidirectional $\mathrm{H}^{+}$secretion and $\mathrm{HCO}_{3}^{-}$secretion occurred.

In conclusion the current studies demonstrate that acute in vitro changes in ambient $\mathrm{PCO}_{2}$ within the physiologic range do not affect net $\mathrm{HCO}_{3}^{-}$transport in the CCT. Conversely, alterations in peritubular $\mathrm{HCO}_{3}^{-}$and $\mathrm{Cl}^{-}$concentration influence net transcellular $\mathrm{HCO}_{3}^{-}$transport. The effect of acute changes in peritubular $\mathrm{HCO}_{3}^{-}$concentration on $\mathrm{J}_{\mathrm{TCO}_{2}}$ in the CCT is independent of $\mathrm{pH}$. From these findings we would suggest that blood $\mathrm{pH}$ is not the prime determinant of net urinary acidification by the CCT. It is unclear whether acute in vivo alterations in ambient $\mathrm{PCO}_{2}$ affect net acidification of the urine by the CCT. Our studies would suggest that if $\mathrm{PCO}_{2}$ does influence the rate of acidification by the CCT, the effect is either indirect, or small, when compared to the effect of altered peritubular anion concentration.

\section{Acknowledgments}

The authors wish to thank Ms. Rebecca Aricheta and Ms. Susan Corona for their skillful technical assistance. In addition, thanks to Dr. Michel Baum for his careful critique of the manuscript.

This work was supported in part from National Institutes of Health training grant 5-T32-AM07257 and National Institutes of Health grants 5-R01-AM23091 and 5-R01-AM14677.

\section{References}

1. Sartorius, O. W., J. C. Rommelt, and R. F. Pitts. 1949. The renal regulation of acid-base balance in man. IV. The nature of renal compensations in ammonium chloride acidosis. J. Clin. Invest. 28:423-439.

2. Lemann, J., Jr., E. J. Lemon, A. D. Goodman, J. R. Litzoq, and A. S. Relman. 1965. The net balance of acid in subjects given large loads of acid or alkali. J. Clin. Invest. 44:507-517.

3. Barker, E. S., R. B. Singer, J. R. Elkinton, and J. K. Clark. 1957. The renal resporise in man to acute experimental respiratory alkalosis and acidosis. J. Clin. Invest. 36:515-529.

4. Lombard, W.E., J. P. Kokko, and H. R. Jacobson. 1983. Bicarbonate transport in cortical and outer medullary collecting tubules. Am. J. Physiol. 244:F289-296.

5. McKinney, T. D., and M. B. Burg. 1977. Bicarbonate transport by rabbit cortical collecting tubules-effect of acid and alkali loads in vivo on transport in vitro. J. Clin. Invest. 60:766-768.

6. Laski, M. E., and N. A. Kurtzman. 1983. Characterization of acidification in the cortical and medullary collecting tubule of the rabbit. J. Clin. Invest. 72:2050-2059.

7. Atkins, J. L., and M. B. Burg. 1983. Secretion and absorption of bicarbonate by rat collecting ducts. Clin. Res. 31:423a. (Abstr.)

8. McKinney, T. D., and M. B. Burg. 1978. Bicarbonate absorption by rabbit cortical collecting tubules in vitro. Am. J. Physiol. 234:F141145.

9. McKinney, T. D., and M. B. Burg. 1978. Bicarbonate secretion by rabbit cortical collecting tubules in vitro. J. Clin. Invest. 61:14211427.

10. Schuster, V. L. 1985. Cyclic adenosine monophosphate-stimulated bicarbonate secretion in rabbit cortical collecting tubules. J. Clin. Invest. 75:2056-2064.

11. Steinmetz, P. R. 1974. Cellular mechanisms of urinary acidifcation. Physiol. Rev. 54:890-956.

12. Gluck, S., C. Cannon, and Q. Al-Awqati. 1982. Exocytosis regulates urinary acidification in turtle bladder by rapid insertion of $\mathrm{H}^{+}$ pumps into the luminal membrane. Proc. Natl. Acad. Sci. USA. 79: 4327-4331.

13. LeFurgey, A., and C. C. Tisher. 1979. Morphology of the rabbit collecting duct. Am. J. Anat. 1555:111-123.

14. Dobyan, D. C., and R. E. Bulger. 1982. Renal carbonic anhydrase. Am. J. Physiol. 243:F311-F324.

15. Schwartz, J. H., D. Bethercourt, and S. Rosen. 1982. Specialized function of carbonic anhydrase-rich and granular cells of turtle bladder. Am. J. Physiol. 242:F627-F633.

16. Madsen, K. M., and C. C. Tisher. 1983. Cellular response to acute respiratory acidosis in rat medullary collecting duct. Am. J. Physiol. 235:F576-F585.

17. Verlander, J. W., K. M. Madsen, and C. C. Tisher. 1985. Two populations of intercalated cells exist in the cortical collecting duct of the rat. Clin. Res. 33:501a. (Abstr.)

18. Schwartz, G. J., and Q. Al-Awqati. 1985. Carbon dioxide causes exocytosis of vesicles containing $\mathrm{H}^{+}$pumps in isolated perfused proximal and collecting tubules. J. Clin. Invest. 75:1638-1644.

19. Schwartz, G. J., and Q. Al-Awqati. 1985. Two functionally distinct 
types of mitochondrial-rich (MR) cells in cortical collecting tubule (CCT) as determined by changes in cell $\mathrm{pH}\left(\mathrm{pH}_{\mathrm{i}}\right)$ in individually identified cells. Kidney Int. 27:288a. (Abstr.)

20. Star, R., M. Knepper, and M. Burg. 1985. Bicarbonate secretion by rabbit cortical collecting duct: role of chloride/bicarbonate exchange. Kidney Int. 27:289a.

21. Laski, M. E., D. G. Warnock, and F. C. Rector. 1983. Effects of chloride gradients on total $\mathrm{CO}_{2}$ flux in the rabbit cortical collecting tubule. Am. J. Physiol. 244:F112-F121.

22. Tomita, K., J. J. Pisano, M. B. Burg, and M. A. Knepper. 1985. Effects of arginine vasopressin and bradykinin on chloride and bicarbonate transport in rat cortical collecting ducts. Clin. Res. 33:500a. (Abstr.)

23. Burg, M., J. Grantham, M. Abramow, and J. Orloff. 1966. Preparation and study of fragments of single rabbit nephrons. Am. J. Physiol. 210:1293-1298.

24. Jacobson, H. R. 1984. Medullary collecting duct acidification: effects of potassium, $\mathrm{HCO}_{3}^{-}$concentration, and $\mathrm{PCO}_{2}$. J. Clin. Invest. 74: 2107-2114.

25. Lucci, M. S., L. R. Pucacco, N. W. Carter, and T. D. DuBose. 1982. Direct evaluation of the permeability of the rat proximal convoluted tubule to $\mathrm{CO}_{2}$. Am. J. Physiol. 242:F470-F476.

26. Jacobson, H. R. 1981. Effects of $\mathrm{CO}_{2}$ and acetazolamide on bicarbonate and fluid transport in rabbit proximal tubules. Am. J. Physiol. 240:F54-F62.

27. Holmberg, C., J. P. Kokko, and H. R. Jacobson. 1981. Determination of chloride and bicarbonate permeabilities in proximal convoluted tubules. Am. J. Physiol. 241:F386-F394.

28. Vurek, G. G., D. G. Warnock, and R. Corsey. 1975. Measurement of picomole amounts of carbon dioxide by calorimetry. Anal. Chem. 47: 765-767.

29. Zar, J. H. 1974. Biostatistical Analysis. Prentice Hall, Inc., Englewood Cliffs, NJ. 77-78.

30. DuBose, T. D., Jr., L. R. Pucacco, D. W. Seldin, N. W. Carter, and J. P. Kokko. 1978. Direct determination of $\mathrm{PCO}_{2}$ in the rat renal cortex. J. Clin. Invest. 62:338-348.

31. Hogg, R. J., L. R. Pucacco, N. W. Carter, A. R. Laptook, and J. P. Kokko. 1984. In situ $\mathrm{PCO}_{2}$ in the renal cortex, liver, muscle, and brain of the New Zealand white rabbit. Am. J. Physiol. 247:F491-F498.
32. Schwartz, J. H. 1976. $\mathrm{H}^{+}$current response to $\mathrm{CO}_{2}$ and carbonic anhydrase inhibition in turtle bladders. Am. J. Physiol. 231:565-572.

33. Cohen, L. H., and P. R. Steinmetz. 1980. Control of active proton transport in turtle urinary bladder by cell pH. J. Gen. Physiol. 76:381393.

34. Koeppen, B. M., and S. I. Helman. 1982. Acidification of luminal fluid by rabbit cortical collecting tubule perfused in vitro. Am. J. Physiol. 242:F521-531.

35. Al-Awqati, Q., A. Mueller, and P. R. Steinmetz. 1977. The transport of $\mathrm{H}^{+}$against electrochemical gradients in turtle urinary bladder. Am. J. Physiol. 233:F502-F508.

36. Al-Awqati, Q. 1978. $\mathrm{H}^{+}$transport in urinary epithelia. Am. J. Physiol. 235:F77-F88.

37. Gluck, S., S. Kelly, and Q. Al-Awqati. 1982. The proton translocating ATPase responsible for urinary acidification. J. Biol. Chem. 257:9230-9233.

38. Gluck, S., and Q. Al-Awqati. 1984. An electrogenic proton translocating adenosine triphosphatase from bovine kidney medulla. J. Clin. Invest. 73:1704-1710.

39. Stone, D. K., D. W. Seldin, J. P. Kokko, and H. R. Jacobson. 1983. Mineralocorticoid modulation of rabbit medullary collecting duct acidification-a sodium independent effect. J. Clin. Invest. 72:77-83.

40. Fisher, J. L., R. F. Husted, and P. R. Steinmetz. 1983. Chloride dependence of the $\mathrm{HCO}_{3}^{-}$exit step in urinary acidification by the turtle bladder. Am. J. Physiol. 245:F564-F568.

41. Stone, D. K., D. W. Seldin, J. P. Kokko, and H. R. Jacobson. 1983. Anion dependence of medullary collecting duct acidification. $J$. Clin. Invest. 71:1505-1508.

42. Leslie, B. R., J. H. Schwartz, and P. R. Steinmetz. 1973. Coupling between $\mathrm{Cl}^{-}$absorption and $\mathrm{HCO}_{3}^{-}$secretion in turtle urinary bladder. Am. J. Physiol. 225:610-617.

43. Cohen, $\mathrm{L}$. $1980 . \mathrm{HCO}_{3}^{-}-\mathrm{Cl}^{-}$exchange transport in the adaptive response to alkalosis by turtle bladder. Am. J. Physiol. 239:F167-F174.

44. Palmisano, J., D. L. Stetson, R. Beauwens, P. Mitchell, and P. R. Steinmetz. 1985. Modification of urinary bicarbonate secretion by cyclic AMP and 9-anthroic acid. Kidney Int. 27:286a. (Abstr.)

45. Sansom, S. C., E. J. Weinman, and R. G. O'Neil. 1984. Microelectrode assessment of chloride-conductive properties of cortical collecting duct. Am. J. Physiol. 247:F291-F302. 